\title{
20. SEDIMENTARY SULFUR AND IRON CHEMISTRY IN RELATION TO THE FORMATION OF EASTERN MEDITERRANEAN SAPROPELS ${ }^{1}$
}

\author{
Hilde F. Passier ${ }^{2}$ and Gert J. de Lange ${ }^{2}$
}

\begin{abstract}
Detailed analyses of total sulfur, pyritic sulfur, humic sulfur, $\mathrm{NaCl}$-extractable sulfur, elemental sulfur, acid-volatile sulfide, and organic polysulfide in and around the most recent Sapropel S1 (maximum $\mathrm{C}_{\mathrm{org}}=2.3 \%$ ) and two other sapropels recovered during Ocean Drilling Program Leg 160 (maximum $\mathrm{C}_{\text {org }}=7.4 \%$ and 23.5\%), show that the main sulfur species in and immediately below each sapropel is pyrite. Directly above each sapropel sulfur is rarely present in the solid phase, but occurs as porewater sulfate $\left(\mathrm{SO}_{4}{ }^{2-}\right)$. Microbial $\mathrm{SO}_{4}{ }^{2-}$ reduction took place in the sapropels during sapropel formation. Addition of reactive iron to sapropel layers occurred via upward diffusion of $\mathrm{Fe}^{2+}$ from underlying sediments and/or through water-column iron sulfide precipitation. All reactive iron that was available in the sediments was used for pyrite formation. As a result, diffusion of sulfide out of the sapropels and sulfidization of the sediments underlying each sapropel have occurred. Only in the most $\mathrm{C}_{\text {org-- }}$ rich sapropel did large-scale uptake of reduced sulfur by organic molecules occur, and $\mathrm{SO}_{4}{ }^{2-}$ reduction probably still continues.
\end{abstract}

\section{INTRODUCTION}

Bacterial sulfate reduction is a common feature in organic-rich sediments in the marine environment (e.g., Canfield, 1989; Mossmann et al.,1991; Calvert and Karlin, 1991). It is part of the complex redox system related to the oxidation of organic matter (Froelich et al., 1979). The sulfur enrichments in the recurrent organic-rich layers (sapropels) in the Eastern Mediterranean prove that these have been subject to bacterial $\mathrm{SO}_{4}{ }^{2-}$ reduction (Van Os et al., 1991; Pruysers et al., 1993; Passier et al., 1996).

The sequence of alternating organic-rich and organic-poor layers in the sedimentary record of the Eastern Mediterranean provides a unique setting to study the different paleoenvironmental and diagenetic signals. During sapropel formation, bacterial sulfate reduction dominated the anoxic sediment at the sediment/water interface, whereas the organic matter oxidation in underlying sediments was dominated by reduction of iron (hydr)oxides. The classic downward succession of oxic, suboxic, and anoxic sediment (Froelich et al., 1979) does not apply to this dynamic system. Relicts of the different redox regimes can be found in the sediment column. For example, enrichments in reduced sulfur species indicate episodes of sulfate reduction, and iron (hydr)oxide-enriched layers indicate boundaries of oxic and suboxic sediments (e.g., Van Santvoort et al., 1996).

A striking feature is that most of the diagenetic alteration of Eastern Mediterranean sediments takes place during and relatively shortly after their formation. Most diagenetic features inferred from sulfur and iron chemistry of Pleistocene sapropels recovered by gravitycoring techniques are also present in the sediments in and around the most recent Holocene Sapropel S1 (5-9 k.y.) (Higgs et al., 1994; Passier et al., 1996; Van Santvoort et al., 1996). In this study we compare the sulfur and iron chemistry of two sapropels of Pliocene age recovered during Ocean Drilling Program (ODP) Leg 160 with the most recent Sapropel S1, to gain insight into the factors that determine the diagenetic history of these sapropels.

${ }^{1}$ Robertson, A.H.F., Emeis, K.-C., Richter, C., and Camerlenghi, A. (Eds.), 1998. Proc. ODP, Sci. Results, 160: College Station, TX (Ocean Drilling Program).

${ }^{2}$ Department of Geochemistry, Institute of Earth Sciences, Utrecht University, PO Box 80.021, 3508 TA Utrecht, The Netherlands. hpassier@earth.ruu.nl

\section{MATERIALS AND METHODS}

Three sapropels were studied. Sapropel S1 in box-core UM26 $\left(33^{\circ} 23.6 \mathrm{~N}, 25^{\circ} 0.9^{\prime} \mathrm{E}\right.$, water depth $\left.2160 \mathrm{~m}\right)$ was recovered $200 \mathrm{~km}$ south of Crete during the 1994 Palaeoflux cruise of Urania. The sapropel, at about $0.24 \mathrm{~m}$ below seafloor (mbsf), is $4 \mathrm{~cm}$ thick. Light gray sediments lie beneath the sapropel; orange-brown sediments lie above it. Part of UM26 was sampled at a resolution of $0.5-1 \mathrm{~cm}$ aboard ship inside an $\mathrm{N}_{2}$-filled glovebox and stored under $\mathrm{N}_{2}$ in airtight containers at $4^{\circ} \mathrm{C}$.

Two sapropels, recovered during Leg 160, were sampled in detail directly after core splitting aboard JOIDES Resolution. One of the Leg 160 sapropels was recovered in Section 160-969E-6H-6. Site $969 \mathrm{E}\left(33^{\circ} 50.5^{\prime} \mathrm{N}, 24^{\circ} 53.0^{\prime} \mathrm{E}\right.$, water depth $\left.2201 \mathrm{~m}\right)$ is located on the Mediterranean Ridge, close to the UM26 site. Hole 969E contains 80 sapropel beds of early Pliocene to Holocene age. The sampled interval contains a 12-cm-thick black sapropel at $50.7 \mathrm{mbsf}$ (at $27 \mathrm{~cm}$ in the section), surrounded by light gray sediments. This sapropel belongs to a group of black sapropels of middle Pliocene age with high organic carbon contents (up to $30 \%$ ) in a gray interval. The dark sapropel has a fine bedding-parallel parting, which may be the result of primary lamination (Emeis, Robertson, Richter, et al., 1996). The other Leg 160 sapropel originates from Section 160-967C-6H-2. Site $967 \mathrm{C}\left(34^{\circ} 4.3^{\prime} \mathrm{N}, 32^{\circ} 43.5^{\prime} \mathrm{E}\right.$, water depth $\left.2553 \mathrm{~m}\right)$ is located on a small ridge near the foot of the northern slope of the Eratosthenes Seamount, about $70 \mathrm{~km}$ south of Cyprus. At this site, 80 sapropels of early Pliocene to Holocene age were recovered. The sampled interval contains a 14-cm-thick sapropel at $49.3 \mathrm{mbsf}$ (at $30 \mathrm{~cm}$ in the section). The sapropel is brownish black and surrounded by gray sediments. It is of late Pliocene age and appears bioturbated. Ten samples $1.5 \mathrm{~cm}$ thick were taken over intervals of 50 and $30 \mathrm{~cm}$ in sections 967C-6H-2 and 969E-6H-6, respectively. The samples were stored under $\mathrm{N}_{2}$ in airtight containers at $4^{\circ} \mathrm{C}$.

Subsamples were dried at $40^{\circ} \mathrm{C}$ (UM26) or freeze-dried (Leg 160) and ground in an agate mortar before dissolution in an $\mathrm{HClO}_{4}-$ $\mathrm{HNO}_{3}-\mathrm{HF}$ acid mixture. The dried residue was dissolved in $1 \mathrm{M} \mathrm{HCl}$ for analysis of total sulfur $\left(\mathrm{S}_{\text {tot }}\right)$, total iron $\left(\mathrm{Fe}_{\text {tot }}\right)$ and total aluminum $\left(\mathrm{Al}_{\text {tot }}\right)$ with a Perkin Elmer OPTIMA 3000 inductively coupled plasma atomic emission spectrometer (ICP-AES). Organic carbon contents were determined with a Fisons Instruments NA-1500 NCS ana- 
lyzer after removal of carbonate in $1 \mathrm{M} \mathrm{HCl} . \mathrm{S}_{\mathrm{tot}}, \mathrm{Fe}_{\mathrm{tot}}, \mathrm{Al}_{\mathrm{tot}}$, and $\mathrm{C}_{\mathrm{org}}$ measurements were performed according to standard laboratory procedures and have standard deviations $<5 \%$. International and inhouse standards were used to check the procedures.

Dried subsamples were extracted with acetone for several hours to remove elemental sulfur (including elemental sulfur formed during drying from acid-volatile sulfide [AVS] and organic polysulfides, and elemental sulfur originally present) before pyrite extraction. Pyrite sulfur $\left(\mathrm{S}_{\text {pyr }}\right)$ was extracted with the $\mathrm{Cr}(\mathrm{II})$ reduction method (Zhabina and Volkov, 1978; Canfield et al., 1986; Cutter and Oatts, 1987; Henneke, 1993; Henneke et al., 1997). AVS (consisting of iron monosulfides) was extracted from wet subsamples in $6 \mathrm{M} \mathrm{HCl}$ under an $\mathrm{N}_{2}$ or Ar atmosphere. $\mathrm{H}_{2} \mathrm{~S}$ that evolved in the pyrite and AVS extractions was stripped from reaction solutions with $\mathrm{N}_{2}$ or $\mathrm{Ar}$ and trapped in $1 \mathrm{M} \mathrm{NaOH}$. The $\mathrm{NaOH}$ solution was analyzed for $\mathrm{HS}^{-}$by square-wave voltammetry (SWV) with a Princeton Applied Research Model 384B-4 polarographic analyzer system equipped with a Model 303A static mercury drop electrode (SMDE).

A sequential extraction procedure (Henneke, 1993; Henneke et al., 1997, based on Francois, 1987, and Ferdelman et al., 1991) was applied to wet subsamples under an $\mathrm{N}_{2}$ atmosphere. First, easily removable sulfur $\left(\mathrm{S}_{\mathrm{NaCl}}\right.$, mostly porewater $\left.\mathrm{S}\right)$ was extracted by $0.5 \mathrm{M}$ $\mathrm{NaCl}$. Then, elemental sulfur $\left(\mathrm{S}_{\text {elem }}\right.$; including low-molecular-weight organic sulfur) was extracted by methanol:toluene $(3: 1)$; pure methanol was used for UM26. Subsequently, organic polysulfides $\left(\mathrm{S}_{\text {orgpol }}\right)$ were broken down to elemental sulfur in $1 \mathrm{M} \mathrm{HCl}$ and extracted by methanol:toluene (3:1); pure methanol was used for UM26. After rinsing the sample with demineralized water, humic sulfur $\left(\mathrm{S}_{\mathrm{NaOH}}\right)$ was extracted by $0.5 \mathrm{M} \mathrm{NaOH}$. Elemental-sulfur-containing-extracts were evaporated and $\mathrm{SO}_{3}{ }^{2-}$ was added to convert elemental sulfur to $\mathrm{S}_{2} \mathrm{O}_{3}{ }^{2-}$, which was determined by (cathodic stripping [CS]) SWV. $\mathrm{NaCl}$ and $\mathrm{NaOH}$ extracts were analyzed for major elements by ICPAES.

The residue of the sequential extraction was dissolved in an $\mathrm{HClO}_{4}-\mathrm{HNO}_{3}-\mathrm{HF}$ acid mixture, dried, and dissolved in $1 \mathrm{M} \mathrm{HCl}$ for analysis of sulfur by ICP-AES. The residual phases of the sequential extraction are pyrite and nonextractable organic sulfur.

The reproducibility of sulfur species analyses appeared dependent of the content and the amount of material available for measurement. Reproducibility was poor for measurements of $S_{\text {orgpol }}$ in samples from Leg 160 sapropels below 1-2 $\mu \mathrm{mol} / \mathrm{g}$ dry, of $S_{\text {elem }}$ in Leg 160 samples below $0.1-0.2 \mu \mathrm{mol} / \mathrm{g}$ dry, and of AVS in all samples below 0.01 $\mu \mathrm{mol} / \mathrm{g}$ dry. These poorly reproducible data showed relative deviations from the mean of $40 \%-145 \%$. All other measurements were satisfactorily reproducible. The average relative deviations from the mean in duplicate measurements were $10 \%$ for pyrite and AVS, $8 \%$ for residual sulfur, $12 \%$ for $\mathrm{S}_{\text {elem }}$ and $\mathrm{S}_{\text {orgpol }}, 5 \%$ for $\mathrm{S}_{\mathrm{NaCl}}$, and $9 \%$ for $\mathrm{S}_{\mathrm{NaOH}}$.

Reactive iron was extracted from wet subsamples in dithionite (acetate/citrate buffer, $\mathrm{pH}=4.8,4 \mathrm{hr}, 60^{\circ} \mathrm{C}$ ) under an $\mathrm{N}_{2}$ atmosphere following the procedure of Kostka and Luther (1994). Dithionite is thought to extract amorphous iron (hydr)oxides, crystalline iron (hydr)oxides, and AVS. The iron concentration in the dithionite extracts was measured by ICP-AES and spectrophotometrically (Köster, 1979). The average relative deviation from the mean in duplicate measurements of reactive iron was $10 \%$.

The water contents of the samples were determined by differences in weight before and after drying.

\section{RESULTS}

Sapropel samples are relatively rich in sulfur and organic carbon $\left(\mathrm{C}_{\text {org }}\right)$ (Fig. 1; Table 1). The predominant sulfur phase in and below each sapropel is $\mathrm{S}_{\mathrm{pyr}}$ (Fig.1; Table 1). Above sapropels, however, humic sulfur $\left(\mathrm{S}_{\mathrm{NaOH}}\right)$ and $\mathrm{S}_{\mathrm{NaCl}}$ are the most important sulfur species
(Fig. 1, Table 1). The $\mathrm{C}_{\text {org }}$ contents of the three sapropels differ significantly: the maxima are $2.3,7.4$, and $23.5 \mathrm{wt} \%$ for the sapropel samples from Core UM26, and Sections 967C-6H-2, $30 \mathrm{~cm}$, and 969E-6H-6, $27 \mathrm{~cm}$, respectively. The $\mathrm{C}_{\text {org }}$ content in nonsapropel samples ranges from 0.1 to $0.6 \mathrm{wt} \%$ (Fig. 1; Table 1).

$\mathrm{S}_{\mathrm{NaCl}}$ is fairly constant in samples from Core UM26 and Section $967 \mathrm{C}-6 \mathrm{H}-2,30 \mathrm{~cm}$, and both cores have similar contents. At the bottom of the sapropel in Section $969 \mathrm{E}-6 \mathrm{H}-6,27 \mathrm{~cm}$, however, the $\mathrm{S}_{\mathrm{NaCl}}$ is 1 order of magnitude higher (Fig. 1; Table 1).

$\mathrm{S}_{\mathrm{NaOH}}$ is enriched in all three sapropel layers: the maximum contents are 27, 71, and $121 \mu \mathrm{mol} / \mathrm{g}$ dry for sapropel samples UM26, 967C-6H-2, $30 \mathrm{~cm}$, and 969E-6H-6, $27 \mathrm{~cm}$, respectively (Fig. 1; Table 1). $\mathrm{S}_{\mathrm{NaOH}}$ below the sapropels is slightly higher than above them. In the $\mathrm{NaOH}$ extraction a small amount of pyrite may be co-extracted. Deduced from the iron contents of the humic extract, less than $15 \%$ of the sulfur extracted by $\mathrm{NaOH}$ in pyrite-rich samples may be pyritic sulfur. This is a maximum percentage, because iron phases other than pyrite dissolve in $0.5 \mathrm{M} \mathrm{NaOH}$ as well.

The main residual sulfur phases of the sequential extraction are pyrite and nonextractable organic sulfur. In most samples, the amount of residual sulfur of the sequential extraction is comparable to or slightly smaller than the amount of pyritic sulfur. Minor losses may have occurred during the sequential extraction procedure. In $969 \mathrm{E}-6 \mathrm{H}-6,27 \mathrm{~cm}$, however, the amount of residual sulfur is greater than the amount of pyritic sulfur (Fig. 2). Accordingly, nonextractable organic sulfur may be present.

$\mathrm{S}_{\text {elem }}$ content is less than $0.06 \mu \mathrm{mol} / \mathrm{g}$ dry in Core UM26, and there is no apparent trend with depth. In contrast, $S_{\text {elem }}$ is enriched to 0.6 $\mu \mathrm{mol} / \mathrm{g}$ dry in $967 \mathrm{C}-6 \mathrm{H}-2,30 \mathrm{~cm}$, and to $23 \mu \mathrm{mol} / \mathrm{g}$ dry in $969 \mathrm{E}-6 \mathrm{H}-$ $6,27 \mathrm{~cm}$, and it correlates positively with the $\mathrm{C}_{\text {org }}$ content (Fig. 1; Table 1). $S_{\text {orgpol }}$ content is less than $2 \mu \mathrm{mol} / \mathrm{g}$ dry in $967 \mathrm{C}-6 \mathrm{H}-2,30 \mathrm{~cm}$, and Core UM26, and there is no noticeable trend with depth. In 969E$6 \mathrm{H}-6,27 \mathrm{~cm}$, though, the $\mathrm{S}_{\text {orgpol }}$ content correlates positively with the $\mathrm{C}_{\text {org }}$ content and is $4.3 \mu \mathrm{mol} / \mathrm{g}$ dry at maximum (Fig. 1; Table 1). AVS contents are low: 0 to $0.4 \mu \mathrm{mol} / \mathrm{g}$ dry in Core UM26, 0.03 to $0.9 \mu \mathrm{mol} /$ $\mathrm{g}$ dry in Section $967 \mathrm{C}-6 \mathrm{H}-2,30 \mathrm{~cm}$, and 0.02 to $0.7 \mu \mathrm{mol} / \mathrm{g}$ dry in Section 969E-6H-6, 27 cm (Fig. 1; Table 1). AVS contents in samples from sapropel S1 measured directly aboard after sampling inside an $\mathrm{N}_{2}$-filled glovebox were in the same range.

Because the AVS contents are relatively small, all dithioniteextractable iron may be considered to represent iron (hydr)oxides. Iron (hydr)oxides ( $\mathrm{Fe}_{\text {dith }}$; Fig. 3; Table 1) are relatively enriched above the sapropels in Section $967 \mathrm{C}-6 \mathrm{H}-2,30 \mathrm{~cm}$, and in Core UM26, and at the base of the sapropel in Section 969E-6H-6, $27 \mathrm{~cm}$.

Independently determined total sulfur contents $\left(S_{\text {tot }} ;\right.$ Fig. 1 ; Table 1) compare well with the sum of all sulfur species recovered in the sequential extraction (Table 2).

\section{DISCUSSION}

\section{NaCl-Extractable Sulfur}

\section{Sulfur Species}

In view of the good correlation with the water content (Fig. 4), the $\mathrm{NaCl}$-extracted sulfur is largely attributable to porewater $\mathrm{SO}_{4}{ }^{2-}$. The average porewater $\mathrm{SO}_{4}^{2-}$ concentration, calculated from the water contents and $\mathrm{S}_{\mathrm{NaCl}}$, is $34 \mathrm{mM}$ (standard deviation $4 \%$ ), without any trend with depth. This is close to the concentration of $\mathrm{SO}_{4}{ }^{2-}$ in Mediterranean seawater $(32 \mathrm{mM})$. The water contents of the Leg 160 samples could not be accurately determined, as the samples had been subject to evaporation aboard ship. Compared to the $\mathrm{S}_{\mathrm{NaCl}}$ values of Core $\mathrm{UM} 26$ and to the $\mathrm{SO}_{4}{ }^{2-}$ porewater concentration measured aboard (Sites 969 and 967, at 50 mbsf: $32 \mathrm{mM}$ ), $\mathrm{S}_{\mathrm{NaCl}}$ in Section $967 \mathrm{C}-6 \mathrm{H}-2$, $30 \mathrm{~cm}$, can be entirely attributed to porewater $\mathrm{SO}_{4}{ }^{2-}$. At the bottom of the sapropel in Section 969E-6H-6, $27 \mathrm{~cm}$, however, the amount of $\mathrm{S}_{\mathrm{NaCl}}$ is excessive compared with porewater $\mathrm{SO}_{4}{ }^{2-}$. A tentative con- 




Figure 1. Content vs. depth profiles of $\mathrm{C}_{\mathrm{org}}, \mathrm{S}_{\text {tot }}$ (total sulfur contents of the samples), $\mathrm{S}_{\mathrm{pyr}}$ (pyritic sulfur, determined by $\mathrm{Cr}(\mathrm{II}) \mathrm{reduction}$ ), $\mathrm{S}_{\mathrm{NaCl}}(\mathrm{NaCl}$-extractable sulfur), $\mathrm{S}_{\mathrm{NaOH}}\left(\mathrm{NaOH}\right.$-extractable, humic sulfur), $\mathrm{S}_{\text {elem }}$ (elemental sulfur including low-molecular-weight organic sulfur), $\mathrm{S}_{\text {orgpol }}$ (organic polysulfides), and AVS (acid-volatile sulfide, extracted with $6 \mathrm{M} \mathrm{HCl}$ ) in samples from Core UM26, and intervals 967C-6H-2, $26-75 \mathrm{~cm}$, and 969E-6H-6, 19-50 cm. The shaded bands indicate the position of the sapropels.

Table 1. Range of contents of $\mathrm{C}_{\text {org }}, \mathrm{S}_{\mathrm{tot}}, \mathrm{S}_{\mathrm{pyr}}, \mathrm{S}_{\mathrm{NaCl}}, \mathrm{S}_{\mathrm{NaOH}}, \mathrm{S}_{\text {elem }}, \mathrm{S}_{\text {orgpol }}, \mathrm{AVS}$, and $\mathrm{Fe}_{\mathrm{dith}}$.

\begin{tabular}{|c|c|c|c|c|c|c|c|c|c|}
\hline Samples & $\begin{array}{c}\mathrm{C}_{\text {org }} \\
(\mathrm{wt} \%)\end{array}$ & $\begin{array}{c}\mathrm{S}_{\mathrm{tot}} \\
(\mu \mathrm{mol} / \mathrm{g} \text { dry })\end{array}$ & $\begin{array}{c}\mathrm{S}_{\mathrm{pyr}} \\
(\mu \mathrm{mol} / \mathrm{g} \text { dry })\end{array}$ & $\begin{array}{c}\mathrm{S}_{\mathrm{NaCl}} \\
(\mu \mathrm{mol} / \mathrm{g} \text { dry })\end{array}$ & $\underset{(\mu \mathrm{mol} / \mathrm{g} \mathrm{dry})}{\mathrm{S}_{\mathrm{NaOH}}}$ & $\underset{(\mu \mathrm{mol} / \mathrm{g} \text { dry })}{\mathrm{S}_{\text {elem }}}$ & $\begin{array}{c}S_{\text {orgpol }} \\
(\mu \mathrm{mol} / \mathrm{g} \text { dry })\end{array}$ & $\begin{array}{c}\text { AVS } \\
(\mu \mathrm{mol} / \mathrm{g} \text { dry })\end{array}$ & $\underset{(\mu \mathrm{mol} / \mathrm{g} \text { dry })}{\mathrm{Fe}_{\text {dith }}}$ \\
\hline \multicolumn{10}{|l|}{ S1, UM26 } \\
\hline Above & $0.3-0.4$ & $56-58$ & $0.3-2$. & $30-33$ & $8-11$ & 0.01 & 0.00 & 0.00 & $70-99$ \\
\hline Within & $0.8-2.3$ & $95-415$ & $25-3 c$ & 25 & $10-27$ & & 0.0 & $0.00-0.01$ & $5-93$ \\
\hline Below & $0.1-0.6$ & $219-317$ & $180-281$ & $16-28$ & $13-26$ & $0.01-0.06$ & $0.13-0.37$ & $0.01-0.43$ & $3-9$ \\
\hline \multicolumn{10}{|c|}{$160-967 \mathrm{C}-6 \mathrm{H}-2,30 \mathrm{~cm}$} \\
\hline Above & & & & J & 0 & 0.0 & & 0. & 12 \\
\hline Within & $5.8-7.4$ & $703-1749$ & $632-1815$ & $25-44$ & $28-71$ & $0.27-0.61$ & $0.12-1.82$ & $0.04-0.95$ & $58-78$ \\
\hline Below & $0.2-0.4$ & $169-589$ & $158-665$ & $18-30$ & $9-17$ & $0.00-0.06$ & $0.01-0.46$ & $0.03-0.06$ & $48-67$ \\
\hline \multicolumn{10}{|c|}{ 160-969E-6H-6, $27 \mathrm{~cm}$} \\
\hline Above & & $130-287$ & $51-14$ & 41 & $16-3$ & 0.0 & $0.20-($ & $0.02-($ & $6-7$ \\
\hline Within & $6-23.5$ & & & $83-29$ & & & & & $27-225$ \\
\hline Below & 0.1 & $240-329$ & $215-222$ & $44-67$ & $34-64$ & $0.00-0.11$ & $0.29-0.56$ & $0.04-0.33$ & $8-10$ \\
\hline
\end{tabular}

Notes: $\mathrm{S}_{\mathrm{tot}}=$ total sulfur, $\mathrm{S}_{\mathrm{pyr}}=$ pyritic sulfur, $\mathrm{S}_{\mathrm{NaCl}}=\mathrm{NaCl}$-extractable sulfur, $\mathrm{S}_{\mathrm{NaOH}}=\mathrm{NaOH}$-extractable, humic sulfur, $\mathrm{S}_{\text {elem }}=$ elemental sulfur, including low-molecular-weight organic sulfur, $\mathrm{S}_{\mathrm{orgpol}}=$ organic polysulfides, $\mathrm{AVS}=$ acid-volatile sulfides, and $\mathrm{Fe}_{\mathrm{dith}}=$ dithionite extractable iron. The values are grouped according to position relative to sapropel.

clusion (see following discussion) from the 1:1 ratio of $\mathrm{Ca}$ and $\mathrm{S}$ in the $\mathrm{NaCl}$ extracts of Section 969E-6H-6, $27 \mathrm{~cm}$, (Fig. 5) is that this enrichment is probably gypsum $\left(\mathrm{CaSO}_{4} \cdot 2 \mathrm{H}_{2} \mathrm{O}\right)$. There is no correlation with sulfur for the elements $\mathrm{Ba}, \mathrm{K}, \mathrm{Sr}$, and $\mathrm{Fe}$ in the $\mathrm{NaCl}$ extracts of Section 969E-6H-6, $27 \mathrm{~cm}$.

\section{Organic Polysulfide Sulfur, Elemental Sulfur, and AVS}

Insignificant amounts of AVS, $S_{\text {elem }}$ and $S_{\text {orgpol }}$, all of which are possible intermediates in pyrite formation (e.g., Luther and Church, 1992) were found in Core UM26 (Fig. 1). Because long-term accumulation of intermediate species is not likely in these marine sediments, the intermediates are indicators for active $\mathrm{SO}_{4}{ }^{2-}$ reduction.
This indicates that no substantial $\mathrm{SO}_{4}{ }^{2-}$ reduction and no pyrite formation presently occur in these sediments. The contents of $S_{\text {orgpol }}$ and $\mathrm{S}_{\text {elem }}$ in Section 969E-6H-6, $27 \mathrm{~cm}$, and $\mathrm{S}_{\text {elem }}$ in Section 967C-6H-2, $30 \mathrm{~cm}$, correlate with the $\mathrm{C}_{\mathrm{org}}$ contents (Fig. 1). These enrichments have formed at places where the sulfide concentrations were high, resulting from in situ $\mathrm{SO}_{4}{ }^{2-}$ reduction, within the sapropel. Elemental sulfur forms from partial oxidation of sulfide, and organic polysulfides form by incorporation of sulfide in organic matter. The contents of AVS, elemental sulfur, and organic polysulfide sulfur are in general higher in Section 969E-6H-6, $27 \mathrm{~cm}$, and 967C-6H-2, $30 \mathrm{~cm}$, than they are in Core UM26, albeit they are still at relatively low levels. This indicates that relatively more $\mathrm{SO}_{4}{ }^{2-}$ reduction occurs, although still at a low level, at present in the older sapropels than in the 


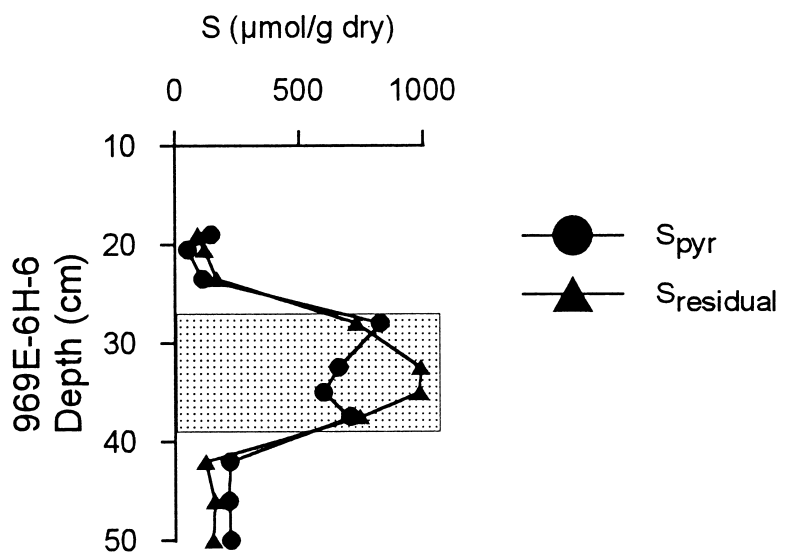

Figure 2. Content vs. depth profiles of $S_{\text {pyr }}$ (pyritic sulfur determined by $\mathrm{Cr}$ (II) reduction) and $\mathrm{S}_{\text {residual }}$ (residual amount of sulfur of the sequential extraction) in interval 969E-6H-6, 19-50 cm. The difference between the two species indicates the presence of nonextractable organic sulfur. The shaded band indicates the position of the sapropel.

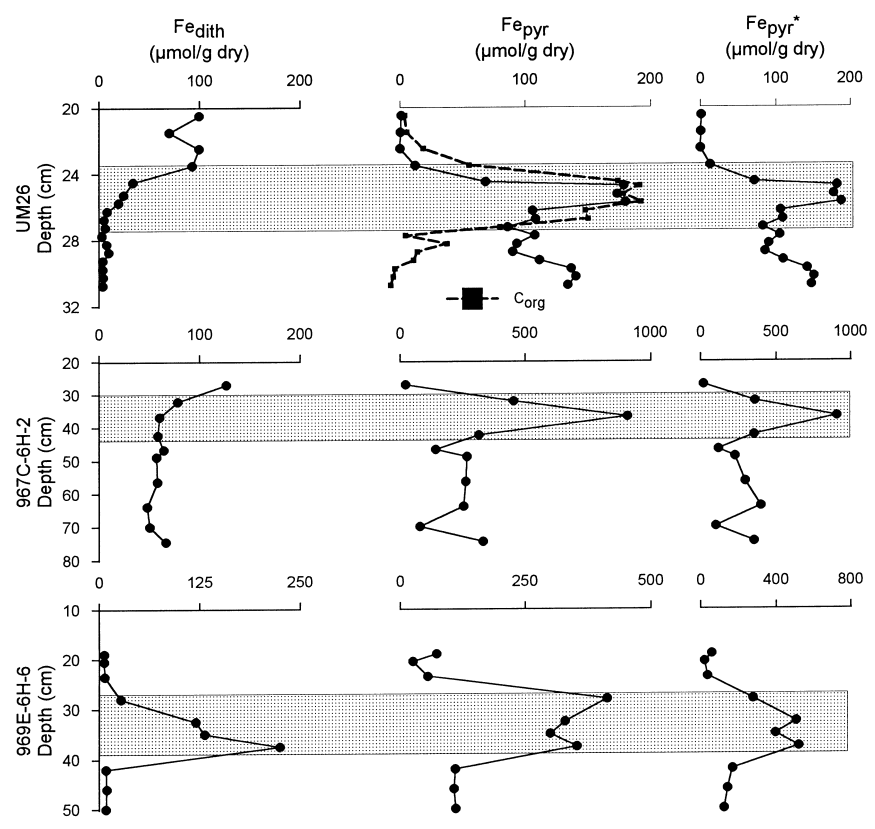

Figure 3. Content vs. depth profiles of $\mathrm{Fe}_{\text {dith }}$ (dithionite-extractable iron), $\mathrm{Fe}_{\text {pyr }}\left(0.5 \times \mathrm{S}_{\mathrm{pyr}}\right.$, with $\mathrm{S}_{\mathrm{pyr}}$ determined by $\mathrm{Cr}(\mathrm{II})$ reduction), and $\mathrm{Fe}_{\mathrm{pyr}} *$ (average $\mathrm{Al}_{\text {tot }} \times \mathrm{Fe}_{\text {pyr }} / \mathrm{Al}_{\text {tot }}$ [normalization to aluminum]) in Core UM26, and intervals $967 \mathrm{C}-6 \mathrm{H}-2,26-75 \mathrm{~cm}$, and $969 \mathrm{E}-6 \mathrm{H}-6,19-50 \mathrm{~cm}$. The shape of the $\mathrm{C}_{\text {org }}$ profile in Core UM26 is also included (for exact contents see Fig. 1). The shaded bands indicate the positions of the sapropels.

youngest sapropel. In addition, low-molecular-weight organic sulfur compounds are included in $\mathrm{S}_{\text {elem }}$; these compounds may be significantly present in the sapropel in Section 969E-6H-6, $27 \mathrm{~cm}$.

A remarkable feature is the enrichment of $\mathrm{NaCl}$-extractable sulfur, probably gypsum (see following discussion), at the base of the sapropel in Section 969E-6H-6, $30 \mathrm{~cm}$ (Fig. 1). This presumed gypsum enrichment is associated with an enrichment of iron (hydr)oxides $\left(\mathrm{Fe}_{\text {dith }}\right.$, Fig. 3), indicating possible oxidation of iron sulfides within the sapropel layer. The oxidation is most likely the result of oxygen contamination during or after sampling. The iron sulfides prone to rapid oxidation are iron monosulfides. Gypsum may be
Table 2. Comparison between the total sulfur content of the sediments and $S_{\text {sum }}$.

\begin{tabular}{lrrr}
\hline Samples & $\begin{array}{c}\text { Total sulfur } \\
(\mu \mathrm{mol} / \mathrm{g} \text { dry })\end{array}$ & $\begin{array}{c}\mathrm{S}_{\text {sum }} \\
(\mu \mathrm{mol} / \mathrm{g} \text { dry })\end{array}$ & $\begin{array}{c}\text { Yield } \\
(\%)\end{array}$ \\
\hline S1, UM26 & & & \\
Above & 56.6 & 46.4 & 82 \\
Within & 281.2 & 227.5 & 81 \\
Below & 256.1 & 178.1 & 70 \\
160-967C-6H-2, $30 \mathrm{~cm}$ & & \\
$\quad$ Above & 53.7 & 49.9 & 93 \\
Within & 1079.1 & 986.1 & 91 \\
Below & 368.2 & 344.2 & 93 \\
160-969E-6H-6, 27 cm & & \\
Above & 216.3 & 192.9 & 89 \\
Within & 1256.2 & 1164.3 & 93 \\
Below & 282.8 & 245.3 & 87 \\
\hline
\end{tabular}

Notes: $S_{\text {sum }}=$ the sum of the sulfur species measured in the sequential extraction, including residual $\mathrm{S}$. The values are averages of samples grouped according to position relative to sapropel.

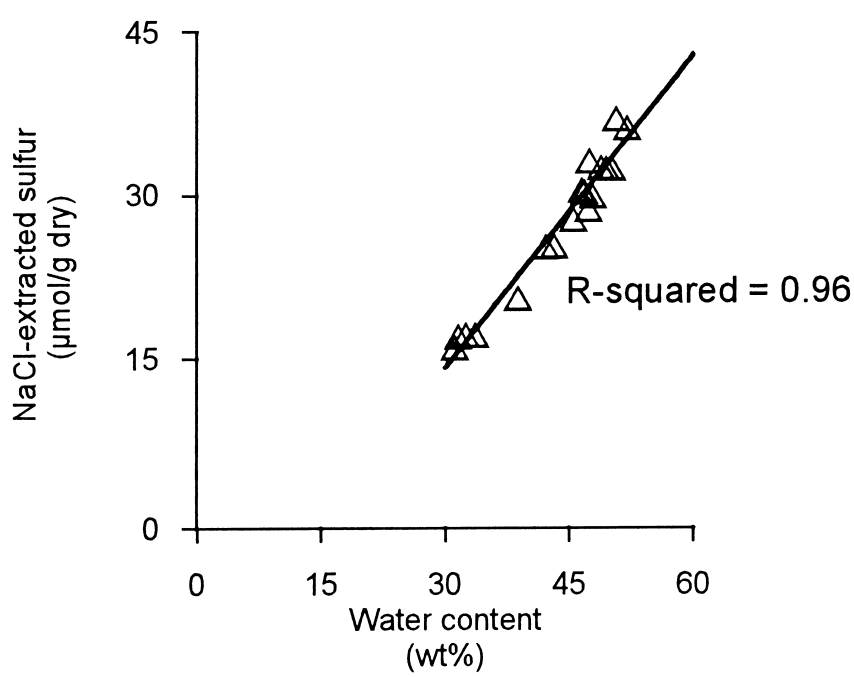

Figure 4. NaCl-extracted sulfur vs. water content in Core UM26.

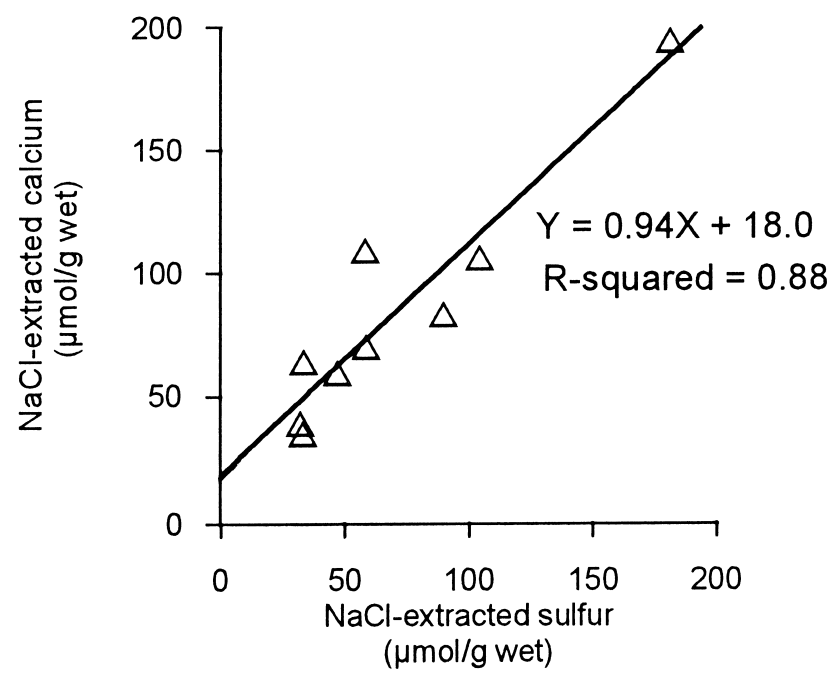

Figure 5. NaCl-extracted calcium vs. NaCl-extracted sulfur in interval 969E$6 \mathrm{H}-6,19-50 \mathrm{~cm}$ 
formed as a consequence of oxidation of iron monosulfides $\left(\mathrm{FeS}_{x}\right.$, in which $x$ is close to 1 ) and dissolution of carbonate tests, according to the following reaction:

$$
\begin{aligned}
& 4 \mathrm{FeS}_{x}+(3+6 x) \mathrm{O}_{2}+(2+12 x) \mathrm{H}_{2} \mathrm{O}+8 x \mathrm{CaCO}_{3} \rightarrow \\
& 4 \mathrm{FeOOH}+4 x \mathrm{CaSO}_{4} \cdot 2 \mathrm{H}_{2} \mathrm{O}+4 x \mathrm{Ca}^{2+}+8 x \mathrm{HCO}_{3}{ }^{-}
\end{aligned}
$$

The ratio of iron (hydr)oxide to $\mathrm{SO}_{4}{ }^{2-}$ in gypsum is $4: 4 x=1: x$. Assuming that all $\mathrm{SO}_{4}{ }^{2-}$ is extracted with $\mathrm{NaCl}$, the 1 : $\mathrm{x}$ ratio can be obtained from the ratio of excess dithionite-extracted iron to excess $\mathrm{NaCl}$-extracted sulfur. The observed ratio is 1:1.07 (Fig. 6), which yields a mean formula for iron sulfide of $\mathrm{Fe}_{0.93} \mathrm{~S}$. This corresponds to a mixture of mackinawite $\left(\mathrm{Fe}_{0.995-1.023} \mathrm{~S}\right.$, Ward, 1970) and greigite $\left(\mathrm{Fe}_{0.75} \mathrm{~S}\right)$, which is the most common association of iron monosulfide minerals found in sediments (Berner, 1967). Moreover, shipboard paleomagnetic measurements of three discrete samples taken immediately after core splitting from the base of the sapropel in Section $969 \mathrm{E}-6 \mathrm{H}-6,27 \mathrm{~cm}$, show a reduction in both magnetic remanence and susceptibility with time. The time-dependent decay in magnetic properties (10\%/day) is consistent with oxidation of a metastable ferrimagnetic iron sulfide (Roberts et al., in press).

Oxidation of iron monosulfides results in the addition of $\mathrm{Ca}^{2+}$ and $\mathrm{SO}_{4}^{2-}$ to the sediment samples and interstitial waters. $\mathrm{Ca}^{2+}$ and $\mathrm{SO}_{4}{ }^{2-}$, which cannot have escaped by diffusion because the cores were sampled within a few hours after core splitting, and the samples are isolated in vials, will be extracted with $\mathrm{NaCl}$. On the basis of reaction (1) one would expect to find a ratio of $\Delta \mathrm{Ca}^{2+}: \Delta \mathrm{SO}_{4}{ }^{2-}=(4 x+4 x): 4 x=2: 1$ in these $\mathrm{NaCl}$ extracts. Nonetheless, the amount of $\mathrm{Ca}^{2+}$ that dissolves will be controlled by the dynamic equilibria of the carbonate system and not just by the stoichiometry of reaction (1). Therefore, detailed mass balance calculations were performed. These calculations predict a linear correlation between $\mathrm{Ca}^{2+}$ and $\mathrm{SO}_{4}{ }^{2-}$ in $\mathrm{NaCl}$ extracts with a slope of 1 (i.e., $\Delta \mathrm{Ca}^{2+}: \Delta \mathrm{SO}_{4}{ }^{2-}=1: 1$; see Appendix). In fact, the correlation between $\mathrm{Ca}^{2+}$ and $\mathrm{SO}_{4}{ }^{2-}$ in $\mathrm{NaCl}$ extracts of the sapropel in $\mathrm{Sec}-$ tion 969E-6H-6, $27 \mathrm{~cm}$, has a slope of 0.94 (i.e., $\Delta \mathrm{Ca}^{2+}: \Delta \mathrm{SO}_{4}{ }^{2-} \approx 1: 1$; Fig. 5). Hence, the observed correlation between $\mathrm{Ca}^{2+}$ and $\mathrm{SO}_{4}{ }^{2-}$ are most likely due to the oxidation of iron monosulfides.

Summarizing, the iron (hydr)oxide and $\mathrm{S}_{\mathrm{NaCl}}$ enrichments at the base of the sapropel in Section 969E-6H-6, $27 \mathrm{~cm}$, indicate the original presence of iron monosulfides $\left(\mathrm{FeS}_{1.07}, \mathrm{AVS}\right)$. This appearance of AVS indicates that active $\mathrm{SO}_{4}{ }^{2-}$ reduction may still occur within this sapropel. $\mathrm{SO}_{4}{ }^{2-}$ reduction either never stopped inside this ex-

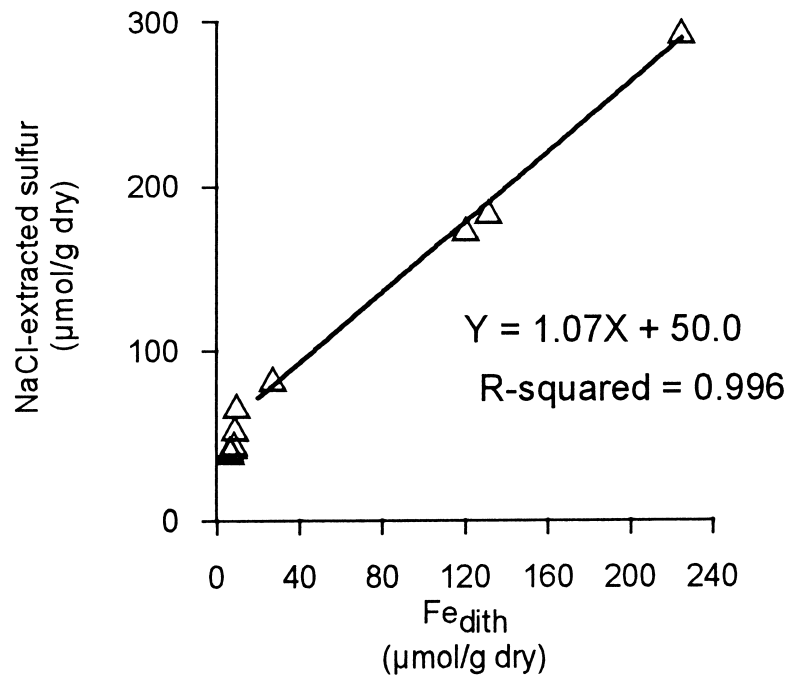

Figure 6. NaCl-extracted sulfur vs. $\mathrm{Fe}_{\text {dith }}$ (dithionite extracted iron) in interval 969E-6H-6, 19-50 cm. tremely $\mathrm{C}_{\text {org }}$-rich layer or started again after some time. Assuming that porewater data for Hole 969A are comparable to those of Hole $969 \mathrm{E}$, the porewater profile of $\mathrm{SO}_{4}{ }^{2-}$ indicates that $\mathrm{SO}_{4}{ }^{2-}$ reduction may only take place at very low rates (Emeis, Robertson, Richter, et al., 1996).

\section{Pyritic Sulfur, Humic Sulfur, and Nonextractable Organic Sulfur}

Most of the sulfide that was formed in the sapropel and retained in the sediment has reacted with iron, and formed pyrite in and below the sapropel (Fig. 1), whereas another portion of the sulfide was incorporated in organic matter. The uptake of reduced sulfur in organic matter results in the fractions humic sulfur $\left(\mathrm{S}_{\mathrm{NaOH}}\right.$, Fig. 1) and nonextractable organic sulfur (deduced from the residual fraction of the sequential extraction). Only in the central part of the sapropel in Section $969 \mathrm{E}-6 \mathrm{H}-6,27 \mathrm{~cm}$, nonextractable organic sulfur is detectable. In sediments with low reactive iron contents, reduced sulfur may be incorporated in the organic fraction of the sediments during early diagenesis (e.g., Sinninghe Damsté and De Leeuw, 1990).

The main sulfur compound below each sapropel is pyrite. The pyrite has been formed as a result of downward diffusion of $\mathrm{HS}^{-}$from the sapropel during formation of the sapropel (Passier et al., 1996). Most of the sulfide that diffused to below the sapropel has reacted with iron (hydr)oxides in the underlying sediments or with upwarddiffusing $\mathrm{Fe}^{2+}$. Sediments below the sapropels, however, are also enriched in humic sulfur $\left(\mathrm{S}_{\mathrm{NaOH}}\right.$, Fig. 1) as compared with sediments above the sapropels. This implies that the humic substances below the sapropels may have incorporated sulfur, during the downward diffusion of $\mathrm{HS}^{-}$.

\section{Storage of Reduced Sulfur and Iron Carbon-Sulfur Relationships}

The $\mathrm{C}_{\text {org }}$ content of the sapropels differs significantly. The 23.5 $\mathrm{wt} \% \mathrm{C}_{\mathrm{org}}$ found in the sapropel in Section 969E-6H-6, $27 \mathrm{~cm}$, is among the highest found in Eastern Mediterranean sediments (Emeis, Robertson, Richter, et al., 1996). The amount of reduced sulfur in sediments is closely related to the $\mathrm{C}_{\text {org }}$ content. This is due to the fact that with increasing amounts of $\mathrm{C}_{\text {org }}$ a larger amount of organic matter is metabolizable and more sulfide is produced (e.g., Berner and Raiswell, 1983; Berner, 1984; Leventhal, 1987). In normal marine sediments the relation between sulfur and carbon contents has a slope of $1 / 2.8\left(\mathrm{~S}_{\mathrm{tot}} / \mathrm{C}_{\text {org }}\right.$ ratio, wt $\left.\% / \mathrm{wt} \%\right)$ and passes through the origin (assuming that sulfur fractions other than reduced sulfur are relatively negligible). In euxinic marine environments, however, sulfide is omnipresent (independent of local $\mathrm{C}_{\text {org }}$ contents) and iron sulfide formation can take place in the water column or at the sediment/water interface. In addition, even slowly reacting iron compounds may react with sulfide in euxinic environments. Consequently, positive intercepts on the sulfur axis are obtained in sulfur vs. carbon plots for euxinic sediments, and only weak correlations may be observed (e.g., Leventhal, 1983; Berner, 1984). Additionally, postdepositional sulfidization of $\mathrm{C}_{\mathrm{org}}$-poor sediments may result in extremely high sulfur/ carbon ratios (Boesen and Postma, 1988; Middelburg, 1991; Leventhal, 1995; Passier et al., 1996).

In $S_{\text {tot }}$ vs. $C_{\text {org }}$ plots of the discussed sapropels (Fig. 7), most samples plot above the normal marine regression line, pointing to euxinic features and postdepositional sulfidization of $\mathrm{C}_{\text {org }}$-poor sediments below the sapropels (Passier et al., 1996). The samples with extremely high $\mathrm{C}_{\text {org }}$ values from the sapropel in Section 969E-6H-6, $27 \mathrm{~cm}$, however, plot below the normal marine line. Reduced sulfur formation and/or uptake in the sediment seems more limited for this part of the sapropel. There are several factors that determine the sulfur content of sediments in which sulfur is predominantly pyrite. Sulfate reduction and subsequent pyrite formation can be limited by (1) the 

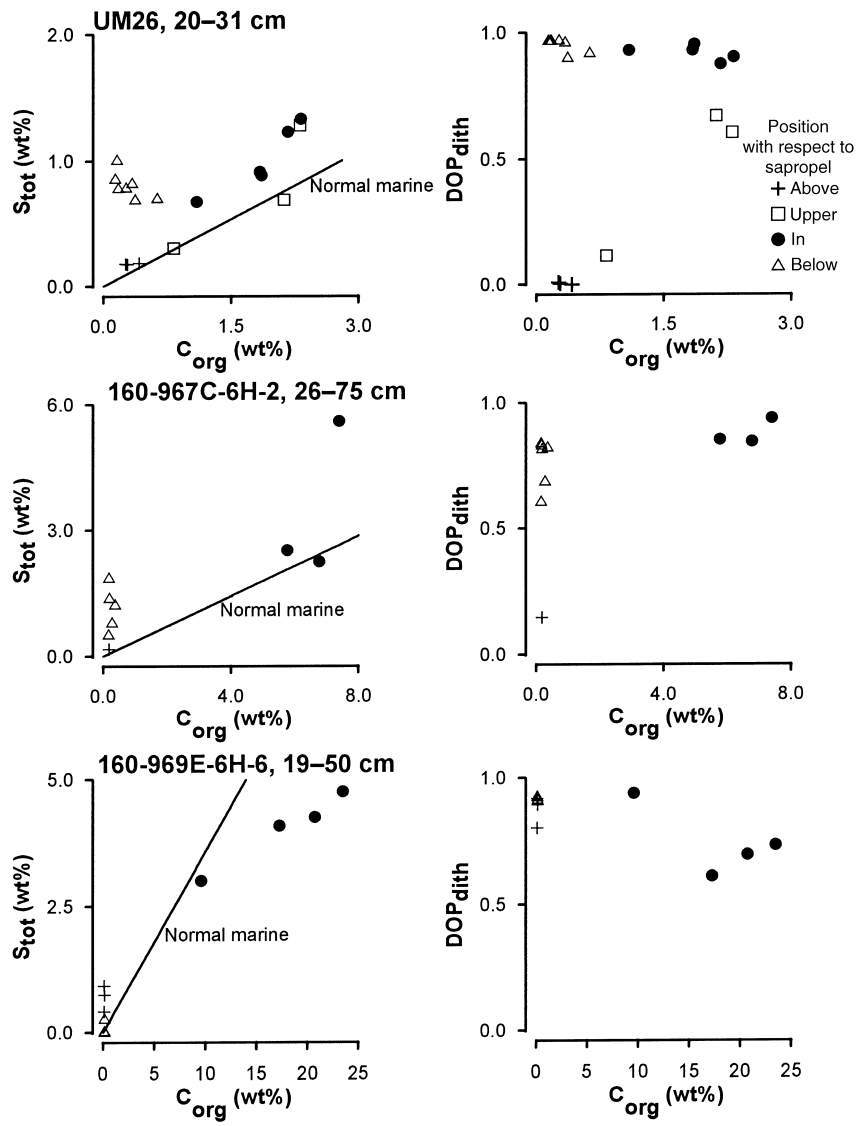

Figure 7. $\mathrm{S}_{\text {tot }}$ and DOP ${ }_{\text {dith }}$ vs. $\mathrm{C}_{\text {org }}$ in Core UM26, 20-31 cm, and intervals $967 \mathrm{C}-6 \mathrm{H}-2,26-75 \mathrm{~cm}$, and 969E-6H-6, 19-50 cm.

availability of $\mathrm{SO}_{4}^{2-}$, (2) amount and reactivity of organic matter, and (3) content and reactivity of iron minerals (e.g., Berner, 1984).

\section{Availability of Sulfate}

The first factor, the availability of $\mathrm{SO}_{4}{ }^{2-}$, is neither the limiting factor in the marine environment where sapropels are formed nor in the present-day interstitial waters of the Eastern Mediterranean. Most of the porewater profiles of $\mathrm{SO}_{4}{ }^{2-}$ in the Eastern Mediterranean demonstrate a downward increase owing to the dissolution of underlying evaporites, like the profiles at Sites 967 and 969 (Emeis, Robertson, Richter, et al., 1996). Preliminary sulfur isotope data and other sedimentary data show that the $\mathrm{SO}_{4}{ }^{2-}$ concentration was not limiting for sulfide formation in the past either.

\section{Reactivity of Organic Matter}

The second factor, the availability of metabolizable organic matter, may be important in the sapropels. Apparently, the organic matter left over after intensive remineralization during and shortly after sapropel formation is no longer sufficiently labile to sustain a sulfatereducing environment in most of the sapropels.

Furthermore, the relatively low sulfur content in the organic-rich samples of Section 969E-6H-6, $27 \mathrm{~cm}$ (Fig. 7), may be in part related to a lower reactivity of the organic matter. The humic sulfur and nonextractable organic sulfur contents in Section 969E-6H-6, $27 \mathrm{~cm}$, are relatively high. Because of the incorporation of sulfur into organic substances, organic matter may become less labile (e.g., Sinninghe
Damsté and De Leeuw, 1990). However, the $\mathrm{C}_{\text {org }}$ content is much higher in Section 969E-6H-6, 27 cm, than in Section 967C-6H-2, 30 $\mathrm{cm}$, and Core UM26. Therefore, it seems unlikely that the uptake of sulfur into organic compounds has significantly affected the total reactivity of organic matter, and thus its reactivity for $\mathrm{SO}_{4}{ }^{2-}$ reduction.

In summary, it seems that the reactivity of organic matter is presently limiting $\mathrm{SO}_{4}{ }^{2-}$ reduction and pyrite formation in most sapropels, but the reason for this is not clear. The mechanisms that determined the extent of pyrite formation in each sapropel during the periods that $\mathrm{SO}_{4}{ }^{2-}$ reduction was not limited by the reactivity of the organic matter are discussed subsequently.

\section{Content and Reactivity of Iron Minerals}

The third limiting factor for pyrite formation, the availability of iron, is usually inferred from plots of the degree of pyritization (DOP) vs. $C_{\text {org }}$ (Raiswell and Berner, 1985). The parameter DOP was proposed by Berner (1970):

$$
D O P=\frac{\text { pyritic } F e}{\text { pyritic Fe }+ \text { reactive Fe }} .
$$

We have taken reactive iron as equal to dithionite-extractable iron, as recommended by Raiswell et al. (1994); DOP values based on dithionite-extractable iron are $\mathrm{DOP}_{\text {dith }}$ values.

The high $\mathrm{DOP}_{\text {dith }}$ values inside the sapropels, independent of $\mathrm{C}_{\text {org }}$ content, suggest that pyrite formation in the sapropels was iron limited (Fig. 7). However, as we explain later, the observed $D \mathrm{P}_{\text {dith }}$ values indicate only that all iron that was supplied to the sediment was stored as pyrite.

Slightly lower $\mathrm{DOP}_{\text {dith }}$ values are found for the $\mathrm{C}_{\text {org }}$-rich samples at the base of the sapropel in Section 969E-6H-6, $27 \mathrm{~cm}$. These deviations are artificial, and they originate from the iron (hydr)oxide enrichment that formed as a result of iron sulfide oxidation, as discussed earlier (Fig. 3). If the oxidized sulfur had diffused out of the system, this would have evoked a deviation in the $S_{\text {tot }}$ vs. $C_{\text {org }}$ plot toward the $\mathrm{C}_{\text {org }}$ axis. Assuming that all oxidized sulfur has been retained in the sediment as gypsum, oxidation of iron sulfides does not influence the $\mathrm{S}_{\text {tot }}$ vs. $\mathrm{C}_{\text {org }}$ plot. Consequently, the relatively low sulfur/carbon ratios in the $\mathrm{C}_{\text {org }}$-rich part of Section 969E-6H-6, $27 \mathrm{~cm}$, cannot be explained by this oxidation.

High $\mathrm{DOP}_{\text {dith }}$ values and high sulfur/carbon ratios are acquired in

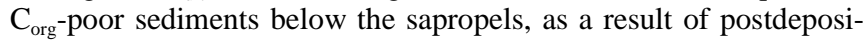
tional sulfidization (Fig. 7). This sulfidization developed as soon as the sulfide production exceeded the iron availability for pyrite formation in the sapropel (Passier et al., 1996). In Core UM26 and Section $967 \mathrm{C}-6 \mathrm{H}-2,30 \mathrm{~cm}$, this sulfidization has affected only the sediments underlying the sapropels and not the overlying sediments. This indicates that only small amounts of $\mathrm{HS}^{-}$may have diffused out of the $\mathrm{C}_{\text {org }}$-rich layers after sapropel formation. In Section 969E-6H-6, 27 $\mathrm{cm}$, however, $\mathrm{DOP}_{\mathrm{dith}}$ values and pyrite contents of the sediments overlying the sapropel are slightly higher than above the other sapropels (Fig. 7). Probably post- or syndepositional sulfidization of the sediments overlying the sapropel in Section 969E-6H-6, $27 \mathrm{~cm}$, has occurred. At the moment it is not clear whether the sulfide source is upward sulfidization of the sapropel in Section 969E-6H-6, $27 \mathrm{~cm}$, or downward $\mathrm{HS}^{-}$diffusion from a younger sapropel.

Relatively low $\mathrm{DOP}_{\text {dith }}$ values at low $\mathrm{C}_{\text {org }}$-contents are found above the sapropels in Core UM26 and Section 967C-6H-2, $30 \mathrm{~cm}$. In the Eastern Mediterranean, sapropel formation is usually followed by a period of downward oxidation of the sediment. $\mathrm{C}_{\text {org }}$ and pyrite are oxidized at the oxidation front, and the front is marked by an iron (hydr)oxide enrichment (De Lange et al., 1989; Pruysers et al., 1993; Van Santvoort et al., 1996). Above the sapropels in Core UM26 and Section 967C-6H-2, $30 \mathrm{~cm}$, such enrichments of iron (hydr)oxides are present (Fig. 3). The iron enrichment above sapropel S1 in Core UM26 indicates active oxidation of the sapropel (Van Santvoort et 
al., 1996), whereas the iron enrichment above Section 967C-6H-2, 30 $\mathrm{cm}$, is thought to be the relict of such a front. No iron (hydr)oxide enrichment is present above Section 969E-6H-6, $27 \mathrm{~cm}$. Either an oxidation front has never been present above this sapropel or any oxidized iron has subsequently been reduced and diffused out of the sediment. It could have been used for pyrite formation elsewhere in the sediment or reacted to pyrite in situ. Accordingly, sediments above Section 969E-6H-6, $27 \mathrm{~cm}$, do not have anomalously low DOP $_{\text {dith }}$ values and the low $\mathrm{DOP}_{\text {dith }}$ values above the other two sapropels are caused by oxidation of pyrite and $\mathrm{C}_{\text {org }}$ and the precipitation of iron (hydr)oxides. The high-resolution samples from Core UM26 (Fig. 3) show that the iron (hydr)oxide-layer "invades" into the top of sapropel $\mathrm{S} 1$; this means that pyrite is more readily oxidized than $\mathrm{C}_{\mathrm{org}}$. Consequently, the sediments from this upper sapropel region have relatively low $\mathrm{DOP}_{\text {dith }}$ values at relatively high $\mathrm{C}_{\text {org }}$ contents. Although the oxidation of pyrite results in $\mathrm{SO}_{4}{ }^{2-}$ formation (Moses et al., 1987), the oxidation at the oxidation front has not led to an enrichment of $\mathrm{SO}_{4}{ }^{2-}\left(\mathrm{S}_{\mathrm{NaCl}}\right.$, Fig. 1) above the sapropels. This indicates that the oxidation is a slow process relative to diffusion of oxidized species away from the front.

The $\mathrm{DOP}_{\text {dith }}$ values lead to the conclusion that the availability of iron has been controlling the amount of pyrite stored within the sapropels. In the next section, we discuss the mechanisms that rule the storage of pyrite in the different sapropels in more detail.

\section{Iron Source, Mobility, and Fixation}

\section{Iron Enrichments}

Iron (hydr)oxides are not depleted in the sapropels relative to the underlying sediments (Fig. 3), although the sulfide concentration must have been higher inside the sapropels (sulfide source) than in the underlying sediments, where sulfide has diffused. In addition, $\mathrm{DOP}_{\text {dith }}$ values and (aluminum-normalized) silicate iron contents $\left(\mathrm{Fe}_{\text {silicate }}=\mathrm{Fe}_{\text {tot }}-\mathrm{Fe}_{\mathrm{pyr}}-\mathrm{Fe}_{\text {dith }}\right.$, and $\mathrm{Fe}_{\text {silicate }}{ }^{*}=$ average $\mathrm{Al}_{\text {tot }} \times \mathrm{Fe}_{\text {silicate }}$ ' $\mathrm{Al}_{\text {tot }}$ ) within the sapropels are as high as those below the sapropels (Fig. 7; Table 3). This indicates that iron from slowly reacting ironbearing silicates has not been detectably used as an extra source for pyrite formation inside the sapropel, where all reactive iron was incorporated in pyrite. If iron from silicates were used more extensively within sapropels, $\mathrm{Fe}_{\text {silicate }}$ would have been lower and $\mathrm{DOP}_{\text {dith }}$ values would have been higher within the sapropel. The pyrite enrichments are not due to any sedimentary dilution effect, as follows from normalization to aluminum content (Fig. 3). As a consequence, because more pyrite has formed within than below the sapropels, there must have been an additional input of iron to the sapropel sediment.

\section{Iron- $C_{\text {org }}$ Relationships}

In a plot of the sum of pyritic iron and dithionite-extractable iron vs. $\mathrm{C}_{\text {org }}$ in the sapropel samples, two groups of data points appear (Fig. 8). It is not important for the interpretation whether $\mathrm{Fe}_{\mathrm{pyr}}+\mathrm{Fe}_{\mathrm{dith}}$ or just $\mathrm{Fe}_{\mathrm{pyr}}$ is used (Fig. 8). To study the limits of pyrite formation,

Table 3. Range of contents of $\mathrm{Fe}_{\text {silicate }}$ and $\mathrm{Fe}_{\text {silicate }}{ }^{*}$.

\begin{tabular}{ccc}
\hline Samples & $\begin{array}{c}\mathrm{Fe}_{\text {silicate }} \\
(\mathrm{mmol} / \mathrm{g} \text { dry })\end{array}$ & $\begin{array}{c}\mathrm{Fe}_{\text {silicate }}{ }^{*} \\
(\mathrm{mmol} / \mathrm{g} \text { dry })\end{array}$ \\
\hline $\begin{array}{l}\text { S1, UM26 } \\
\text { Within }\end{array}$ & $247-265$ & $255-265$ \\
Below & $212-259$ & $220-254$ \\
160-967C-6H-2, & $30 \mathrm{~cm}$ & \\
Within & $328-421$ & $333-368$ \\
Below & $229-456$ & $281-698$ \\
160-969E-6H-6, 27 cm \\
Within \\
Below & $107-379$ & $158-543$ \\
& $180-551$ & $202-727$ \\
\hline
\end{tabular}

Notes: $\mathrm{Fe}_{\text {silicate }}=\mathrm{Fe}_{\mathrm{tot}}-\mathrm{Fe}_{\mathrm{pyr}}-\mathrm{Fe}_{\text {dith. }} . \mathrm{Fe}_{\text {silicate }}{ }^{*}=$ average $\mathrm{Al}_{\text {tot }} \times \mathrm{Fe}_{\text {silicate }} / \mathrm{Al}_{\text {tot }}$. The values are grouped according to position relative to sapropel. we used a plot of $\mathrm{Fe}_{\text {pyr }}$ vs. $\mathrm{C}_{\text {org }}$ instead of $\mathrm{S}_{\text {tot }}$ vs. $\mathrm{C}_{\text {org }}$ because organic sulfur is also included in $\mathrm{S}_{\text {tor }}$. The first group of data points is situated at relatively low $\mathrm{C}_{\mathrm{org}}$ contents, including samples from Core UM26 and Section $967 \mathrm{C}-6 \mathrm{H}-2,30 \mathrm{~cm}$, and the second group at relatively high $\mathrm{C}_{\text {org }}$ contents represents Section 969E-6H-6, 27 cm (Fig. 8). Sedimentary dilution may be an important factor in the interpretation of enrichments in sediments. Therefore, the data were normalized with respect to $\mathrm{Al}_{\text {tot }}$, assuming that aluminum fluxes to the sediment have remained constant. Plots of aluminum-normalized values of $\mathrm{Fe}_{\mathrm{pyr}}(+$ $\mathrm{Fe}_{\mathrm{dith}}$ ) vs. aluminum-normalized values of $\mathrm{C}_{\text {org }}$ yield the same general distinction between samples from Core UM 26 and Section 967C$6 \mathrm{H}-2,30 \mathrm{~cm}$, on one hand and samples from Section 969E-6H-6, 27 $\mathrm{cm}$, on the other (Fig. 8). The uppermost sample, with the lowest $\mathrm{C}_{\text {org }}$ content, from the sapropel in Section 969E-6H-6, $27 \mathrm{~cm}$, is separated from the $\mathrm{C}_{\mathrm{org}}$-rich samples of this sapropel, and plots in the same area as samples from Core UM26 and Section 967C-6H-2, $30 \mathrm{~cm}$. For the first group a positive correlation between $\mathrm{C}_{\text {org }}$ contents and iron is discernible. The second group has a lower iron content, relative to $\mathrm{C}_{\mathrm{org}}$, and the iron content is independent of $\mathrm{C}_{\text {org }}$.

Positive correlations between $\mathrm{C}_{\text {org }}$ and the sum of pyritic and reactive iron have been observed in previous studies of organic-rich sediments (Raiswell and Berner, 1985; Raiswell and Al-Biatty, 1989). This correlation may be either a diagenetic or a depositional feature.

The input of detrital iron to sediments may vary as a result of climate-related changes in weathering and erosion (Raiswell and AlBiatty, 1989). However, the most extremely $\mathrm{C}_{\text {org }}$-rich sapropel (Section $969 \mathrm{E}-6 \mathrm{H}-6,27 \mathrm{~cm}$ ), which is probably related to the most extreme climate changes, contains relatively little amounts of iron (Figs. 3, 8). Accordingly, an increase of detrital iron input does not

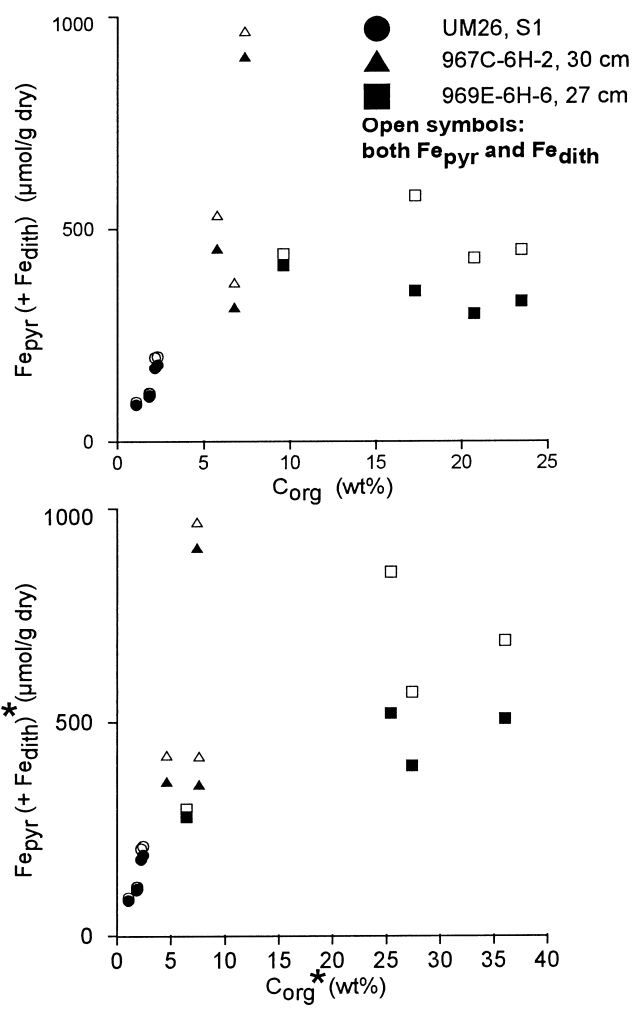

Figure 8. $\mathrm{Fe}_{\mathrm{pyr}}\left(+\mathrm{Fe}_{\mathrm{dith}}\right)$ vs. $\mathrm{C}_{\mathrm{org}}$ in sapropel samples from Core UM26, and intervals $967 \mathrm{C}-6 \mathrm{H}-2,26-75 \mathrm{~cm}$, and 969E-6H-6, 19-50 cm. $\mathrm{Fe}_{\mathrm{pyr}}=0.5 \times$ $\mathrm{S}_{\mathrm{pyr}}, \mathrm{S}_{\mathrm{pyr}}$ is determined by $\mathrm{Cr}(\mathrm{II})$ reduction, and $\mathrm{Fe}_{\mathrm{dith}}$ is dithionite-extractable iron. Asterisks indicate that the data have been normalized to aluminum content, for example: $\mathrm{C}_{\text {org }} *$ average $\mathrm{Al}_{\text {tot }} \times \mathrm{C}_{\text {org }} / \mathrm{A}_{\text {ltot }}$. 
seem to be an important additional iron source during sapropel formation. Assuming that the input of detrital reactive iron is constant, there are two additional sources of iron during sapropel formation: (1) diffusion of $\mathrm{Fe}^{2+}$ from the underlying sediment to the sediment/ water interface and (2) iron sulfide formation from dissolved $\mathrm{Fe}^{2+}$ and sulfide in the water column.

In these situations the supply of iron may be coupled to the $\mathrm{C}_{\text {org }}$ content via sulfide production. Positive iron vs. $\mathrm{C}_{\text {org }}$ correlations indicate that more $\mathrm{SO}_{4}{ }^{2-}$ reduction has occurred and more pyrite has formed because more $\mathrm{C}_{\text {org }}$ is present. The mechanisms of pyrite enrichment and the correlation to the $\mathrm{C}_{\text {org }}$ content are discussed below.

\section{Iron Addition via Diffusion from Underlying Sediments}

A mechanism to explain the addition of iron and coupling between iron and $\mathrm{C}_{\text {org }}$ is that upward-diffusing $\mathrm{Fe}^{2+}$ is used for pyrite formation within the sapropel at times of relatively low sulfide production. Any diffusing $\mathrm{Fe}^{2+}$ that is not scavenged by pyrite formation in the sapropel may be oxidized near the sediment/water interface or may escape into the water column. In sediments with a higher $\mathrm{C}_{\text {org }}$ content, more metabolizable organic matter was originally present. Consequently, more $\mathrm{SO}_{4}{ }^{2-}$ reduction and fixation of sulfide as pyrite was possible, leading to a positive correlation between $\mathrm{Fe}_{\text {pyr }}$ and $\mathrm{C}_{\text {org }}$. In this situation, sulfide production, and thus indirectly the reactivity of organic matter toward $\mathrm{SO}_{4}{ }^{2-}$ reduction determines the extent of pyrite formation, and sulfide consumes all available iron. The fixation of upward-diffusing $\mathrm{Fe}^{2+}$ as pyrite within the sapropel is possible only when the sulfide production is relatively small. When sulfide production is larger than the sum of the upward $\mathrm{Fe}^{2+}$ flux and detrital reactive iron input, sulfide will diffuse out of the sapropel and will meet upward-diffusing $\mathrm{Fe}^{2+}$ below it. Pyrite formation takes place below the sapropel, and the upward $\mathrm{Fe}^{2+}$ flux does not reach the sapropel. In that case, pyrite formation within the sapropel is limited by the amount of detrital reactive iron.

For sapropel S1, recent porewater fluxes of $\mathrm{Fe}^{2+}$ have been compared to the amount of iron fixed as pyrite within and below the sapropel (Passier et al., 1997). This comparison indicates that upward diffusion of $\mathrm{Fe}^{2+}$ during sapropel formation and detrital iron combined could have supplied all fixed iron. Similar calculations for older sapropels are difficult, because $\mathrm{Fe}^{2+}$ fluxes, detrital iron inputs, and duration of periods of sapropel formation are not known.

The amounts of iron fixed as pyrite in Sections 967C-6H-2, 30 $\mathrm{cm}$, and 969E-6H-6, $27 \mathrm{~cm}$, are higher than in Core UM26 (Fig. 8). Preliminary sulfur isotope measurements indicate that pyrite formation was probably not significant after burial of the sapropels. A similar conclusion was drawn for Pleistocene and Holocene sapropels (Passier et al., 1996, 1997). Hence, significant iron addition via diffusion from underlying sediments probably also stopped after burial, with the possible exception of the iron fixed as AVS and maybe some of the pyrite at the base of the sapropel in Section 969E-6H-6, $27 \mathrm{~cm}$. The larger fixation of iron in Sections $967 \mathrm{C}-6 \mathrm{H}-2,30 \mathrm{~cm}$, and 969E$6 \mathrm{H}-6,27 \mathrm{~cm}$, compared with Core UM26 may also arise from a larger input of detrital reactive iron and/or a larger upward flux of $\mathrm{Fe}^{2+}$. Within and below the sapropel in Section $967 \mathrm{C}-6 \mathrm{H}-2,30 \mathrm{~cm}, \mathrm{Fe}_{\mathrm{dith}}$ is higher than within and below the other sapropels (Fig. 3). This site is close to Cyprus; consequently, the detrital input and flux of $\mathrm{Fe}^{2+}$ may have been larger here. However, there is no reason to assume a larger detrital iron input in Section 969E-6H-6, $27 \mathrm{~cm}$, than in Core UM26, as the sites are close to each other. In addition, iron and $\mathrm{C}_{\text {org }}$ are not coupled in Section 969E-6H-6, $27 \mathrm{~cm}$. Moreover, it was argued previously that the input of detrital iron did not increase significantly during sapropel formation. The scenario described here (i.e., pyrite enrichment via addition of upward-diffusing $\mathrm{Fe}^{2+}$ ) may yield only an uncoupled iron and $\mathrm{C}_{\text {org }}$ situation in the sapropel when downward sulfidization occurs: in this case, detrital reactive iron is the only available iron for pyrite formation, and the absolute pyrite enrichment in this sapropel cannot be explained. Another mechanism of pyrite for- mation seems to be important in the sapropel in Section 969E-6H-6, $27 \mathrm{~cm}$, which is discussed in the following section.

\section{Iron Addition via Iron Sulfide Formation in the Water Column}

Iron addition may also arise from the precipitation of iron sulfides in a euxinic water column. This mechanism was recently proposed for the Black Sea, where a large part of the water column contains sulfide and iron may be liberated from sediments in suboxic zones along the basin margins (Canfield et al., 1996). This process may result in the coupling of iron and $\mathrm{C}_{\text {org }}$ : the more $\mathrm{C}_{\text {org }}$ rains down, the more sulfide will be present in the water column, and the more iron sulfides can precipitate in the water column, thus inducing a positive correlation between $\mathrm{C}_{\mathrm{org}}$ and $\mathrm{Fe}_{\mathrm{pyr}}$ in the sediment. However, the water-column iron sulfide that is added to the sediments in euxinic basins is usually independent of the $\mathrm{C}_{\text {org }}$ content, because sulfide is omnipresent and not necessarily related to the local $\mathrm{C}_{\text {org }}$ content. In addition, the amount of iron sulfide that is formed in the water column may be limited by the thickness of the sulfidic layer in the water column (e.g., Leventhal, 1983, 1987). In the sapropel in Section 969E$6 \mathrm{H}-6,27 \mathrm{~cm}, \mathrm{Fe}_{\mathrm{pyr}}\left(+\mathrm{Fe}_{\mathrm{dith}}\right)$ is higher within the sapropel than below the sapropel and independent of the $\mathrm{C}_{\text {org }}$ content (Fig. 8). Thus, addition of iron from the water column may have resulted in the relative pyrite enrichment inside the sapropel in Section 969E-6H-6, $27 \mathrm{~cm}$. No coupling of iron and $\mathrm{C}_{\text {org }}$ is visible; so, no significant pyrite was formed from upward-diffusing $\mathrm{Fe}^{2+}$ in the sapropel. Apparently, upward-diffusing $\mathrm{Fe}^{2+}$ could not reach the sapropel because downward sulfidization occurred permanently during sapropel formation, implying a constantly high sulfide production. This observation is in agreement with the occurrence of iron sulfide formation in the water column, and the implicit presence of sulfide in the bottom water: when downward sulfide diffusion occurs out of a sapropel, sulfide is also expected to diffuse upward to the bottom water. Sulfide may be oxidized at the sediment/water interface or in the bottom water, but when the sulfide flux is relatively large, sulfidic bottom waters may develop. Furthermore, when downward sulfidization takes place, pyrite formation within the sapropel is iron limited and uptake of sulfur in organic substances may be important (e.g., Sinninghe Damsté and De Leeuw, 1990). Hence, the presence of high amounts of organic sulfur in Section 969E-6H-6, $27 \mathrm{~cm}$, can be explained.

\section{Consequences of the Imbalance Between Sulfide Production and the Addition of Iron}

In summary, in these sediments with predominantly syngenetic pyrite, the absence or presence of a positive correlation between $\mathrm{Fe}_{\mathrm{pyr}}$ $\left(+\mathrm{Fe}_{\mathrm{dith}}\right)$ and $\mathrm{C}_{\mathrm{org}}$ may indicate the site of pyrite formation: in the water column (absence of correlation) or at the sediment/water interface (positive correlation).

Because mechanisms such as sulfidization of adjacent sediments and iron addition to the sediments are possible in the alternating $\mathrm{C}_{\mathrm{org}}{ }^{-}$ rich and $\mathrm{C}_{\text {org }}$-poor sediments in the Eastern Mediterranean, the site of $\mathrm{SO}_{4}{ }^{2-}$ reduction does not necessarily coincide with the location of pyrite formation. Although iron sulfide formation may be (temporarily) limited within a sapropel, sulfide production within this layer may result in the formation of iron sulfides in the water column or below the sapropel. As the sulfidization of organic-poor sediments below sapropels invokes high sulfur/carbon ratios, the sediments from where the sulfur originates will have lower sulfur/carbon ratios when sulfide diffuses out of the source sediment (sapropel). Downward sulfidization has been important during the formation of the sapropel in Section 969E-6H-6, $27 \mathrm{~cm}$, as a result of the extremely high $\mathrm{C}_{\text {org }}$ content. This may explain the apparent sulfur deficiency in these sediments (Fig. 7). In contrast, as long as downward sulfidization does not occur, the supply of $\mathrm{Fe}^{2+}$ to the sapropel results in a higher fixation capacity for sulfide within the sapropels, and thus in higher $\mathrm{S}_{\text {tot }}$ contents. This is expressed by the fact that many sapropel samples lie 
far above the normal marine regression line in $\mathrm{S}_{\text {tot }}$ vs. $\mathrm{C}_{\text {org }}$ plots (e.g., Section 967C-6H-2, $30 \mathrm{~cm}$, and Core UM26; Fig. 7).

\section{CONCLUSIONS}

The elevated $\mathrm{C}_{\text {org }}$ contents of sapropels have induced anoxic, sulfate-reducing sedimentary conditions and the fixation of reduced sulfur. Pyrite is the main sulfur species in the sediments in and below the sapropels. The presence of AVS in the extremely organic-rich (up to $23.5 \%$ ) sapropel in Section 969E-6H-6, $27 \mathrm{~cm}$, indicates that detectable, but slow, sulfate reduction still occurs in that interval.

Two postdepositional changes are important in the cyclic sediments in the Eastern Mediterranean: (1) sulfidization of sapropel-underlying sediments during sapropel formation, and (2) oxidation of sapropel and overlying sediments after sapropel burial. The sulfidization results in elevated pyrite contents, and, to a lesser extent, in elevated humic sulfur contents below each sapropel. Furthermore, sulfidization of the sediments both underlying and overlying a sapropel may happen around extremely organic-rich sapropels, where sulfate reduction continues after sapropel formation.

The iron sources for pyrite formation may comprise (1) $\mathrm{Fe}^{2+}$ diffusing upward from underlying sediments, (2) detrital iron, and (3) water-column iron through iron sulfide formation in the water column. Syngenetic pyrite formation during sapropel development takes place at the sediment/water interface or in the water column. Watercolumn iron sulfide formation has probably been important in the most organic-rich (up to 23.5\%) sapropel (in Section 969E-6H-6, 27 $\mathrm{cm}$ ), implying that the bottom waters contained sulfide during a substantial part of the formation of this sapropel. During the formation of sapropels with lower $\mathrm{C}_{\text {org }}$ contents, iron sulfide formation in the water column, and thus sulfidic bottom waters, were probably not as important.

Addition of iron to the site of sulfide production, the sapropel, results in higher sulfur fixation relative to the $\mathrm{C}_{\text {org }}$ content in sapropels, whereas downward sulfidization results in a lower fixation of sulfur relative to $\mathrm{C}_{\text {org }}$ content within the sapropels. Although sulfur fixation is enhanced below a sapropel, sulfur may also escape upward into the bottom water during periods of downward sulfidization. This escaped reduced sulfur may either oxidize at the chemocline or form iron sulfide in the water column.

The enrichment of $\mathrm{Fe}_{\mathrm{pyr}}$ in the sediments is controlled primarily by the amount of iron that is added to the sediment interval and fixed by direct iron sulfide formation, rather than by the amount of detrital Fe: when more iron is added by diffusion from underlying sediments or by precipitation of iron sulfides in the water column, more pyrite is found in the sediments. The extent of the $\mathrm{Fe}_{\mathrm{pyr}}$ enrichment within sapropels depends on the relative magnitudes of the sulfide production in the sapropel and the addition of iron to the sapropel during its formation.

\section{ACKNOWLEDGMENTS}

P.R. van der Linde (Geochemistry, Utrecht University) is gratefully acknowledged for doing the equilibrium calculations on the oxidation of sulfides, presented in the Appendix. M.E. Böttcher (ICBM, Oldenburg University) is thanked for the preliminary sulfur isotope measurements. Chief scientist C. Corselli, NIOZ technicians, and Captain Lubrano and his crew are thanked for their cooperation during the cruise with Urania. H.C. de Waard, D. van der Meent, R. Alink, G.N. Nobbe, and P.G.J. Anten provided valuable assistance in the lab. C.H. van der Weijden is thanked for critically reading the manuscript. The journal reviewers K. Wallman and M.E. Böttcher, as well as editor K.-C. Emeis are thanked for their constructive comments. This study was supported by the Netherlands Organization of
Scientific Research (NWO/GOA, in particular GJdL by grant \#750.00.620-7290), the MAST-2 Palaeoflux programme (\#MAS2CT93-0051), and the Cosiglio Nazionale della Ricerche (CNR). This is publication \#970131 of the Netherlands Research School of Sedimentary Geology.

\section{REFERENCES}

Berner, R.A., 1967. Thermodynamic stability of sedimentary iron sulphides. Am. J. Sci., 265:777-785.

1970. Sedimentary pyrite formation. Am. J. Sci., 268:1-23.

1984. Sedimentary pyrite formation: an update. Geochim. Cosmochim. Acta, 48:605-615.

Berner, R.A., and Raiswell, R., 1983. Burial of organic carbon and pyrite sulfur in sediments over Phanerozoic time: a new theory. Geochim. Cosmochim. Acta, 47:855-862.

Boesen, C., and Postma, D., 1988. Pyrite formation in anoxic environments in the Baltic. Am. J. Sci., 288:575-603.

Calvert, S.E, and Karlin, R.E., 1991. Relationships between sulphur, organic carbon, and iron in modern sediments of the Black Sea. Geochim. Cosmochim. Acta, 55:2483-2490.

Canfield, D.E., 1989. Sulfate reduction and oxic respiration in marine sediments: implications for organic carbon preservation in euxinic environments. Deep-Sea Res. Part A, 36:121-138.

Canfield, D.E., Lyons, T.W., and Raiswell, R., 1996. A model for iron deposition to euxinic Black Sea sediments. Am. J. Sci., 296:818-834.

Canfield, D.E., Raiswell, R., Westrich, J.T., Reeves, C.M., and Berner, R.A., 1986. The use of chromium reduction in the analysis of reduced inorganic sulfur in sediments and shale. Chem. Geol., 54:149-155.

Cutter, G.A., and Oatts, T.J., 1987. Determination of dissolved sulfide and sedimentary sulfur speciation using gas chromatography photoionization detection. Anal. Chem., 59:717-721.

de Lange, G.J., Middelburg, J.J., and Pruysers, P.A., 1989. Discussion: Middle and Late Quaternary depositional sequences and cycles in the Eastern Mediterranean. Sedimentology, 36:151-158.

Emeis, K.-C., Robertson, A.H.F., Richter, C., et al., 1996. Proc. ODP, Init. Repts., 160: College Station, TX (Ocean Drilling Program).

Ferdelman, T., Church, T.M., and Luther, G.W., III, 1991. Sulfur enrichment of humic substances in a Delaware salt marsh sediment core. Geochim. Cosmochim. Acta, 55:979-988.

Francois, R., 1987. A study of the extraction conditions of sedimentary humic acids to estimate their true in situ sulfur content. Limnol. Oceanogr., 32:964-972

Froelich, P.N., Klinkhammer, G.P., Bender, M.L., Luedtke, N.A., Heath, G.R., Cullen, D., Dauphin, P., Hammond, D., Hartman, B., and Maynard, V., 1979. Early oxidation of organic matter in pelagic sediments of the eastern equatorial Atlantic: suboxic diagenesis. Geochim. Cosmochim. Acta, 43:1075-1090

Henneke, E., 1993. Early diagenetic processes and sulfur speciation in pore waters and sediments of the hypersaline Tyro and Bannock Basins, eastern Mediterranean [Ph.D. thesis]. Utrecht Univ., Geol. Ultraiectina, 108.

Henneke, E., Luther, G.W., III, De Lange, G.J., and Hoefs, J., 1997. Sulphur speciation in anoxic hypersaline sediments from the Eastern Mediterranean Sea. Geochim. Cosmochim. Acta, 61:307-321.

Higgs, N.C., Thomson, J., Wilson, T.R.S., and Croudace, I.W., 1994. Modification and complete removal of eastern Mediterranean sapropels by postdepositional oxidation. Geology, 22:423-426.

Köster, H.M., 1979. Die chemische Silikatanalyse: Berlin (Springer-Verlag).

Kostka, J.E., and Luther, G.W., III, 1994. Partitioning and speciation of solid phase iron in saltmarsh sediments. Geochim. Cosmochim. Acta, 58:1701-1710.

Leventhal, J.S., 1983. An interpretation of carbon and sulfur relationships in Black Sea sediments as indicators of environments of deposition. Geochim. Cosmochim. Acta, 47:133-137.

, 1987. Carbon and sulfur relationships in Devonian shales from the Appalachian Basin as an indicator of environment of deposition. Am. J. Sci., 287:33-49.

1995. Carbon-sulfur plots to show diagenetic and epigenetic sulfidation in sediments. Geochim. Cosmochim. Acta, 59:1207-1212.

Luther, G.W., III, and Church, T.M., 1992. An overview of the environmental chemistry of sulfur in wetland systems. In Howarth, R.W., Stewart, J.W.B., and Ivanov, M.V. (Eds.), Sulfur Cycling on the Continents: New York (John Wiley and Sons), 125-142. 
Middelburg, J.J., 1991. Organic carbon, sulphur, and iron in Recent semieuxinic sediments of Kau Bay, Indonesia. Geochim. Cosmochim. Acta, 55:815-828.

Morel, F.M.W., and Hering, J.G., 1993. Principles and Applications of Aquatic Chemistry: New York (Wiley).

Moses, C.O., Nordstrom, D.K., Herman, J.S., and Mills, A.L., 1987. Aqueous pyrite oxidation by dissolved oxygen and by ferric iron. Geochim. Cosmochim. Acta, 51:1561-1571.

Mossmann, J.R., Aplin, A.C., Curtis, C.D., and Coleman, M.L., 1991. Geochemistry of inorganic and organic sulphur in organic-rich sediments from the Peru Margin. Geochim. Cosmochim. Acta, 55:3581-3595.

Passier, H.F., Middelburg, J.J., de Lange, G.J., and Böttcher, M.E., 1997. Pyrite contents, microtextures and sulphur isotopes in relation to formation of the youngest Eastern Mediterranean sapropel. Geology, 25:519522.

Passier, H.F., Middelburg, J.J., Van Os, B.J.H., and De Lange, G.J., 1996. Diagenetic pyritization under Eastern Mediterranean sapropels caused by downward sulphide diffusion. Geochim. Cosmochim. Acta, 60:751-763.

Pruysers, P.A., de Lange, G.J., Middelburg, J.J., and Hydes, D.J., 1993. The diagenetic formation of metal-rich layers in sapropel-containing sediments in the eastern Mediterranean. Geochim. Cosmochim. Acta, 57:527-536.

Raiswell, R., and Al-Biatty, H.J., 1989. Depositional and diagenetic C-S-Fe signatures in early Paleozoic normal marine shales. Geochim. Cosmochim. Acta, 53:1147-1152.

Raiswell, R., and Berner, R.A., 1985. Pyrite formation in euxinic and semieuxinic sediments. Am. J. Sci., 285:710-724.

Raiswell, R., Canfield, D.E., and Berner, R.A., 1994. A comparison of iron extraction methods for the determination of degree of pyritisation and the recognition of iron-limited pyrite formation. Chem. Geol., 111:101-110.

Roberts, A.P., Stoner, J.S., and Richter, C., in press. Diagenetic magnetic enhancement of sapropels from the eastern Mediterranean Sea. Mar. Geol.

Sinninghe Damsté, J.S., and De Leeuw, J.W., 1990. Analysis, structure and geochemical significance of organically-bound sulfur in the geosphere: state of the art and future research. Org. Geochem., 16:1077-1101.

Van Os, B.J.H., Middelburg, J.J., and de Lange, G.J., 1991. Possible diagenetic mobilisation of barium in sapropelic sediment from the Eastern Mediterranean. Mar. Geol., 100:125-136.

Van Santvoort, P.J.M., de Lange, G.J., Thomson, J., Cussen, H., Wilson, T.R.S., Krom, M.D., and Ströhle, K., 1996. Active post-depositional oxidation of the most recent sapropel (S1) in sediments of the Eastern Mediterranean. Geochim. Cosmochim. Acta., 60:4007-4024.

Ward, J.C., 1970. The structure and properties of some iron sulfides. Rev. Pure Appl. Chem., 20:175-206.

Whitfield, M., 1974. The ion-association model and the buffer capacity of the carbon dioxide system in seawater at $25^{\circ} \mathrm{C}$ and 1 atmosphere total pressure. Limnol. Oceanol., 19:235-248.

Zhabina, N.N., and Volkov, I.I., 1978. A method of determination of various sulfur compounds in sea sediments and rocks. In Krumbein, W.E. (Ed.), Environmental Biogeochemistry and Geomicrobiology (Vol. 3): Ann Arbor (Ann Arbor Sci. Publ.), 735-746.

\section{Date of initial receipt: 6 January 1997 \\ Date of acceptance: 6 June 1997 \\ Ms 160SR-020}

\section{APPENDIX}

Oxidation of sedimentary $\mathrm{FeS}_{x}$, in which $x$ is close to one, and consequent changes in $\mathrm{Ca}, \mathrm{SO}_{4}$, and $\mathrm{Fe}$ chemistry were modeled. The net oxidation reaction is

$$
\begin{aligned}
& 4 \mathrm{FeS}_{\times}+(3+6 \times) \mathrm{O}_{2}+(2+4 \times) \mathrm{H}_{2} \mathrm{O} \rightarrow \\
& 4 \mathrm{FeOOH}+8 \times \mathrm{H}^{+}+4 \times \mathrm{SO}_{4}^{2-} .
\end{aligned}
$$

Reaction (A1) corresponds to the formation of sulfuric acid in the calcareous sediment.
As a result, carbonate dissolves, and $\mathrm{Ca}^{2+}$ is liberated. The addition of sulfuric acid to the sediment can be modeled as the addition of an amount of acid to a calcite suspension, using the basic interpretation of the alkalinity as a balance of charges (e.g., Morel and Hering, 1993):

$$
\begin{aligned}
& \text { Alk = excess negative charge from weak acids } \\
& =\text { excess positive charge from strong base, }
\end{aligned}
$$

we obtain:

$$
\begin{aligned}
& \text { Alk }=\left[\mathrm{OH}^{-}\right]-\left[\mathrm{H}^{+}\right]+\left[\mathrm{HCO}_{3}^{-}\right]+2\left[\mathrm{CO}_{3}^{2-}\right]+\ldots \\
& =\left[\mathrm{Na}^{+}\right]+\left[\mathrm{K}^{+}\right]+2\left[\mathrm{Ca}^{2+}\right]+2\left[\mathrm{Mg}^{2+}\right]-\left[\mathrm{Cl}^{-}\right]-2\left[\mathrm{SO}_{4}^{2-}\right]+\ldots
\end{aligned}
$$

In the "acid-addition" experiment, all terms om the right-hand side, except $\left[\mathrm{Ca}^{2+}\right]$ and $\left[\mathrm{SO}_{4}{ }^{2-}\right]$, are constant. Consequently,

$\left[\mathrm{Ca}^{2+}\right]=\left[\mathrm{SO}_{4}^{2-}\right]+1 / 2 \times\left(\left[\mathrm{OH}^{-}\right]-\left[\mathrm{H}^{+}\right]+\left[\mathrm{HCO}_{3}^{-}\right]+2\left[\mathrm{CO}_{3}^{2-}\right]\right)+$ constant.

Even when we use the exact definition of alkalinity (e.g., Morel and Hering, 1993) and take into account the formation of carbonate complexes, which comprise about $35 \%$ of the total dissolved carbonate in seawater (e.g., $\mathrm{NaCO}_{3}{ }^{-}$and $\mathrm{CaCO}_{3}{ }^{0}$ ), the same equation (i.e., A4) is obtained.

According to Equation $\mathrm{A} 4,\left[\mathrm{Ca}^{2+}\right]:\left[\mathrm{SO}_{4}{ }^{2-}\right]=1: 1$, on the condition that the second term on the right-hand side ("TERM," half the alkalinity, neglecting carbonate complexes) is relatively constant.

To study the response of this term to the addition of sulfuric acid, chemical equilibrium calculations on a simple model system were done. This model system closely resembles the sedimentary situation at Hole 969A at 51.34 mbsf from which pore waters were analyzed (Emeis, Robertson, Richter, et al., 1996). This sedimentary environment is assumed to be present in the sapropel in Section 160-969E-6H-6, $27 \mathrm{~cm}$, before $\mathrm{FeS}_{x}$ is oxidized. This model system consists of an inert electrolyte at $0.72 \mathrm{M}, 31.8-\mathrm{mM}$ sulfate, 38.7-mM acid, and calcite (solid); from this system 18.9- $\mathrm{mM} \mathrm{CO}_{2}$ has been withdrawn; the temperature is $25^{\circ} \mathrm{C}$ and the pressure is $1 \mathrm{~atm}$. In this system equilibrium with atmospheric $\mathrm{CO}_{2}$ is not taken into account, because the pore waters were analyzed and sediment samples were stored in closed vials only a few hours after core splitting, whereas the $\mathrm{CO}_{2}$ gas-solution equilibration times are in the order of days $\left(\mathrm{FeS}_{x}\right.$ oxidation takes place between core splitting and storage). The vials have minimal headspace; therefore, equilibrium with $\mathrm{CO}_{2}$ (gas) can be neglected as well. For this system, neglecting the formation of complexes, the following values were calculated: $\left[\mathrm{Ca}^{2+}\right]=19.7$ $\mathrm{mM},\left[\mathrm{SO}_{4}{ }^{2-}\right]=31.8-\mathrm{mM}$, and $\left[\mathrm{OH}^{-}\right]-\left[\mathrm{H}^{+}\right]+\left[\mathrm{HCO}_{3}{ }^{-}\right]+2\left[\mathrm{CO}_{3}{ }^{2-}\right]=0.760-$ $\mathrm{mM}$. The shipboard measurements of these parameters at $51.34 \mathrm{mbsf}$ in Hole $969 \mathrm{~A}$ are $\left[\mathrm{Ca}^{2+}\right]=21.7-\mathrm{mM},\left[\mathrm{SO}_{4}{ }^{2-}\right]=31.8-\mathrm{mM}$, and alkalinity $=1.882-\mathrm{meq} /$ $\mathrm{L}$ (Emeis, Robertson, Richter, et al., 1996). Regarding the fact that in seawater about $90 \%$ of $\mathrm{Ca}$ is present as free $\mathrm{Ca}^{2+}$ and the $\left(\left[\mathrm{OH}^{-}\right]-\left[\mathrm{H}^{+}\right]+\left[\mathrm{HCO}_{3}^{-}\right]+\right.$ $2\left[\mathrm{CO}_{3}{ }^{2-}\right]$ ) contributes approximately $65 \%$ of the alkalinity (Whitfield, 1974), this model can be considered reasonable for the sediment samples before oxidation.

The addition of sulfuric acid, representing the oxidation of $\mathrm{FeS}_{x}$, to the initial system described previously was modeled. The variation in the second term on the right-hand of Equation A4 ("TERM"), as a function of the total sulfate concentration (which is proportional to the amount of acid added), is given in Figure A1. Compared to the changes in $\left[\mathrm{Ca}^{2+}\right]$ and $\left[\mathrm{SO}_{4}{ }^{2-}\right]$, this term appears to be practically constant, resulting in a linear relationship, with a slope of 1 , between $\left[\mathrm{SO}_{4}{ }^{2-}\right]\left(\left[\mathrm{H}_{2} \mathrm{SO}_{4}\right]_{\text {added }}\right)$ and $\left[\mathrm{Ca}^{2+}\right]$ (Fig. A1). In these calculations it was assumed that $\mathrm{CO}_{2}$ (gas), possibly evolved during oxidation, was conserved in the system. However, when the loss of $\mathrm{CO}_{2}$ (gas), which occurs during transfer of the sample to an $\mathrm{N}_{2}$ atmosphere, is included in the calculations, the linear relationship between $\left[\mathrm{Ca}^{2+}\right]$ and $\left[\mathrm{SO}_{4}{ }^{2-}\right]$ is maintained.

$\mathrm{The} \mathrm{pH}$ variation is also shown in Figure A1. Because the $\mathrm{pH}$ decreases to below the $\mathrm{pK}_{\mathrm{a}}$ value (6.15 for seawater) of the $\mathrm{H}_{2} \mathrm{CO}_{3} / \mathrm{HCO}_{3}{ }^{-}$equilibrium, the linear correlation between $\left[\mathrm{Ca}^{2+}\right]$ and $\left[\mathrm{SO}_{4}{ }^{2-}\right]$ can easily be seen when reaction (1) (see "Discussion" section) is rewritten with $\mathrm{H}_{2} \mathrm{CO}_{3}$ as the principal component, rather than $\mathrm{HCO}_{3}^{-}$. 


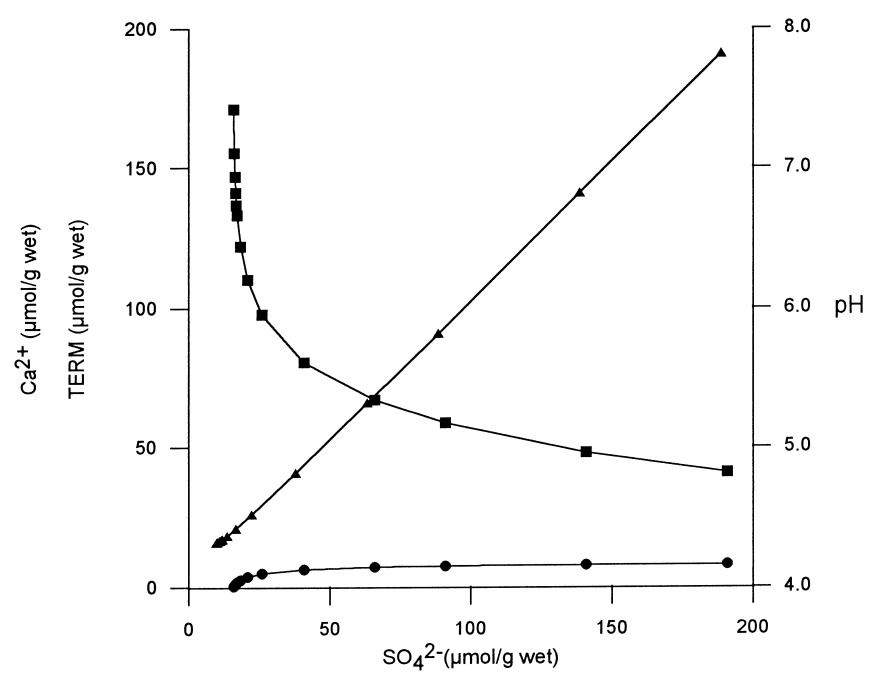

Figure A1. The calculated values of ${ }^{1 / 2} \times\left(\left[\mathrm{OH}^{-}\right]-\left[\mathrm{H}^{+}\right]+\left[\mathrm{HCO}_{3}{ }^{-}\right]+2\left[\mathrm{CO}_{3}{ }^{2-}\right]\right)$ ("TERM," circles), $\left[\mathrm{Ca}^{2+}\right]$ (triangles), and pH (squares) as a function of the total concentration of $\mathrm{SO}_{4}{ }^{2-}$ (initial $\left[\mathrm{SO}_{4}{ }^{2-}\right]+$ added sulfuric acid). The data are expressed in contents in wet sediment ( $\mu$ mol/g wet), enabling direct comparison to the data depicted in Figure 5. A water content of $50 \%$ is assumed $(y \mathrm{mM}=0.5 \times y \mu \mathrm{mol} / \mathrm{g}$ wet). 